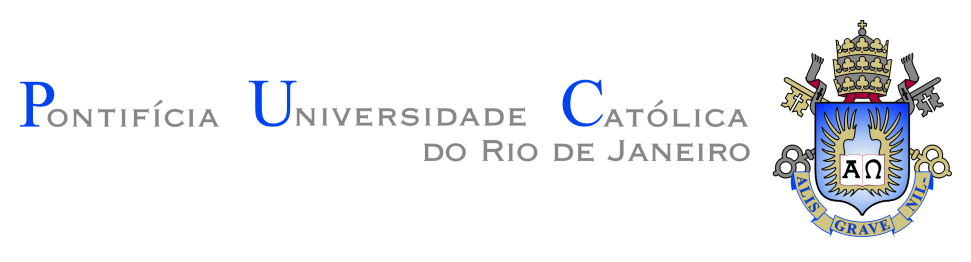

Daniel Cardoso de Salles

Information asymmetry in Brazilian credit market of SMEs' investment loans

\author{
Dissertação de Mestrado
}

Thesis presented to the Programa de Pós-graduação em Economia, do Departamento de Economia da PUC-Rio in partial fulfillment of the requirements for the degree of Mestre em Economia .

Advisor: Prof. Leonardo Rezende

Rio de Janeiro

May 2020 


\section{Information asymmetry in Brazilian credit market of SMEs' investment loans}

Thesis presented to the Programa de Pós-graduação em Economia da PUC-Rio in partial fulfillment of the requirements for the degree of Mestre em Economia. Approved by the Examination Committee:

Prof. Leonardo Rezende

Advisor

Departamento de Economia - PUC-Rio

Prof. Klenio de Souza Barbosa SKEMA Business School

Prof. Vinicius Nascimento Carrasco

Departamento de Economia - PUC-Rio 
All rights reserved.

\section{Daniel Cardoso de Salles}

Graduação em Engenharia de Produção na Universidade Federal do Rio de Janeiro, 2013.

Engenheiro no Banco Nacional de Desenvolvimento - BNDES com atuação no setor de infraestrutura, desde 2013

Bibliographic data

de Salles, Daniel Cardoso

Information asymmetry in Brazilian credit market of SMEs' investment loans / Daniel Cardoso de Salles; advisor: Leonardo Rezende. - 2020.

63 f: il. color. ; $30 \mathrm{~cm}$

Dissertação (mestrado) - Pontifícia Universidade Católica do Rio de Janeiro, Departamento de Economia , 2020.

Inclui bibliografia

1. Economia - Teses. 2. Organização Industrial - Teses. 3. Informação Assimétrica. 4. Financiamentos de investimentos. 5. Micro pequenas e médias empresas. I. Rezende, Leonardo. II. Pontifícia Universidade Católica do Rio de Janeiro. Departamento de Economia. III. Título.

CDD: 330 


\section{Acknowledgments}

Agradeço:

Primeiramente, a minha família: meus pais, meu irmão, meus avós e meus tios. Vocês me inspiram a buscar constantemente aprender e me motivam a evoluir para poder orgulhá-los.

À Stella, meu amor, pelo apoio e paciência incondicionais. Nada seria possível sem você do meu lado.

Aos meus amigos, os mesmos de sempre, para sempre, pela companhia e risadas que me faziam esquecer dos problemas.

Ao professor Leonardo pelos ensinamentos que me fizeram descobrir no enorme "mundo" da economia aquilo que mais me interessava. Aos membros da banca, Prof Klenio e Vinicius, pelos valiosos conselhos e críticas.

Aos meus amigos no BNDES que, em meio aos horários malucos e estressantes, me animaram a continuar. Ao Arian e à Nathalia pela confiança e ajuda para que eu pudesse superar o desafio de conciliar o mestrado com o trabalho.

À equipe do FGI que gentilmente me abriu as portas para conduzir esse estudo.

Esse estudo foi financiado em parte pela Coordenação de Aperfeiçoaento de Pessoal de Nível Superior - Brasil (CAPES) - 001 


\section{Abstract}

de Salles, Daniel Cardoso; Rezende, Leonardo (Advisor). Information asymmetry in Brazilian credit market of SMEs' investment loans. Rio de Janeiro, 2020. 63p. Dissertação de Mestrado Departamento de Economia , Pontifícia Universidade Católica do Rio de Janeiro.

This paper investigates the presence of moral hazard and adverse selection in the credit market of investment loans granted to micro, small and medium enterprises in Brazil. Using a novel database of over 15 thousand indirect credit operations from BNDES, we explore BNDES distinct credit granting policy and the horizontal changes over time in the offered credit conditions conditions for identification. The results indicate that moral hazard is a relevant phenomenon and that its effect is partially attenuated by advantageous selection in loans with subsidized interest rates.

\section{Keywords}

Asymmetric Information; Investment Loans; Micro small and medium enterprise. 


\section{Resumo}

de Salles, Daniel Cardoso; Rezende, Leonardo. Problemas de informação assimétrica no mercado de crédito brasileiro de financiamentos para investimento de micro, pequenas e médias empresas. Rio de Janeiro, 2020. 63p. Dissertação de Mestrado - Departamento de Economia , Pontifícia Universidade Católica do Rio de Janeiro.

Essa dissertação investiga a presença de risco moral e de seleção adversa no mercado de crédito brasileiro de financiamento para investimento de micro, pequenas e médias empresas. Usando uma nova base de dados com mais de 15 mil operações de crédito indiretas do BNDES, nós exploramos uma especificadade das políticas de crédito do BNDES e mudanças periódicas nas condições de crédito ofertadas para identificação. Os resultados indicam que o risco moral é um fenômeno relevante que é parcialmente atenuado por seleção vantajosa nos empréstimos com taxas subsidiadas

\section{Palavras-chave}

Informação Assimétrica; Financiamentos de investimentos; Micro pequenas e médias empresas. 


\section{Table of contents}

$1 \quad$ Introduction $\quad 12$

1.1 Asymmetric Information in Credit Markets 14

2 Sources of Identification $\quad 19$

$\begin{array}{llr}3 & \text { Data } & 23\end{array}$

4 Empirical Approach $\quad 30$

5 Results $\quad 34$

5.1 Loan Demand Regression 34

5.2 Default Regressions 36

5.2.1 Risk Assessment Analysis 40

6 Robustness Test $\quad 42$

6.1 Others Specifications for Default Regression 42

6.2 Chiaporie Salanie Test 44

$\begin{array}{lll}6.3 & \text { Event Study } & 45\end{array}$

$\begin{array}{ll}6.4 & \text { Alternative default specification }\end{array}$

$\begin{array}{lll}7 & \text { Exploring the Enhancement Decision } & 51\end{array}$

8 Conclusion $\quad 55$

9 Appendix $\quad 62$ 


\section{List of figures}

Figure 3.1 Histograms of \% Payed before Default 28

(3.1(a)) by risk type 28

(3.1(b)) by borrower's size 28

$\begin{array}{lll}\text { Figure } 3.2 \% \text { of defaulted loans by leverage range } & 29\end{array}$

Figure $3.3 \%$ of defaulted loans in restricted and unre$\begin{array}{ll}\text { stricted leverage ranges } & 29\end{array}$

Figure 6.1 Histograms of \% Payed before Loan Acceleration 47

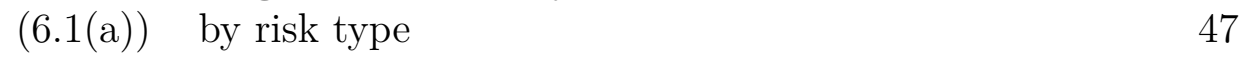

(6.1(b)) by borrower's size 47

Figure 6.2 Spread demanded to overcome default pattern of an average loan in the sample $\quad 50$ 


\section{List of tables}

Table 2.1 Reforms in BNDES credit conditions 20

Table 2.2 Test for the equality of means between loans granted in three months window around credit reforms 21

Table 2.3 Example of changes in BNDES credit lines 21

Table 3.1 Sample division by risk rating and borrowers' size 25

Table 3.2 Descriptive Statistics from the sample 26

Table 5.1 Credit demand regression 35

Table 5.2 Default regression pooling moral hazard and adverse selection $\quad 37$

Table 5.3 Default regression segregating moral hazard and adverse selection $\quad 39$

Table 5.4 Default regression omitting risk-assessment 41

Table 6.1 Default regression with alternative specifications 43

Table 6.2 Chiappori and Salanie (2000) test of asymmetric information 44

Table 6.3 Default regression in reform bordering subsample 46

Table 6.4 Default regression with alternative default definition 48

Table 7.1 Descriptive Statistics of the subsample of loans that could take the enhancement option 52

Table 7.2 Default regression with enhancement decision 53

Table A.1 Non-censored credit demand 63 


\section{List of Abreviations}

BNDES - Banco Nacional de Desenvolvimento Economico e Social

FGI - Fundo Garantidor de Investimento

SMEs - Small and Medium-sized enterprises, equivalente no Brasil a

Micro, Pequenas e Médias empresas

CMN - Conselho Monetário Nacional

BACEN - Banco Central do Brasil

SCR - Sistema de Informações de Crédito do Banco Central

IBGE - Instituto Brasileiro de Geografia e Estatística

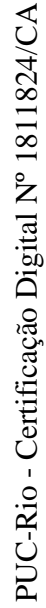

SEBRAE - Serviço Brasileiro de Apoio às Micro e Pequenas Empresas

TJLP - Taxa de Juros de Longo Prazo

TLP - Taxa de Longo Prazo 


\section{Introduction}

Economic theory relates asymmetric information problems, such as moral hazard and adverse selection, to several inefficiencies, and credit markets are traditionally hypothesized to be exposed to these sort of problems. However, the direct empirical identification of moral hazard and adverse selection is challenging due to the confounding effects of these two phenomenon, usually depending on experimental/randomization or on structural approaches to attain separation.

The present paper adapts the semi-structural approach of Adams, Einav, and Levin (2009) seminal paper to investigate empirically the presence of moral hazard and adverse selection in the context of investment loans granted to micro, small and medium enterprises (following the literature we will refer to them as SMEs) in Brazil.

To do so we use a novel database of over 15 thousand BNDES indirect credit operations secured with credit insurance from the Fundo Garantidor para Investimentos (FGI). The identification strategy explores a specificity of the Brazilian Development Bank, the Banco Nacional de Desenvolvimento Economico e Social (BNDES), that sets a limit on the maximum allowable leverage for each credit line. Specifically, horizontal changes in these limits for leverage, which can be assumed independent from the pool of borrowers, create quasi-experimental (instrumental) variation that enables the separation of moral hazard and selection effects in the choice of leverage.

BNDES indirect loans are originated by intermediary banks who pass along BNDES resources, bearing the risk of the loan before BNDES and in exchange charging a spread over the interest rate of BNDES credit line. Also, all the loans in the sample contracted a credit insurance, the FGI, an on first demand guarantee covering from $10 \%$ to $80 \%$ of the total loan.

Our dataset contains all the information available for the BNDES and the FGI about the loan conditions and the borrowers of the indirect loans, notably the risk assessment of the borrower provided by the intermediary bank. So our informational perspective put us in the position of BNDES and FGI to assess whether they experience asymmetric information regarding the final borrowers.

The distinction of adverse selection (hidden information) from moral 
hazard (hidden action) is critical from a policy and practical perspective (Karlan and Zinman (2009)). Adverse selection should motivate policymakers and lenders to consider subsidies, loan guarantees, information coordination (through credit registers and private bureaus) and enhanced screening strategies. Moral hazard should motivate policymakers to consider legal reforms in the areas of liability, garnishment and bankruptcy, and lenders to adopt enhanced dynamic contracting schemes (for example Giné, J. Goldberg, and Yand (2012) documents how credible dynamic incentives can prevent defaults).

This paper fits in the literature estimating moral hazard and adverse selection in credit markets and contributes to the field in three ways.

First, the empirical investigation of asymmetric information in credit markets tends to focus on consumer loans, and investigations of firms loans are still scarce, mostly because of a lack of comparability in the loans conditions. BNDES indirect loans secured by FGI have a standard in financing and guarantees conditions that circumvents this issue.

Second, by placing the investigation of asymmetric information in the market of credit to SMEs in Brazil. SMEs literature largely reports that these firms faces bigger liquidity constrains to grow and are highly dependent on banks for outside finance (Beck and Demirguç-Kunt (2006), Ambrozio, Souza, and Faleiros (2017)), which makes a diagnostic of the presence of asymmetric information between these firms and banks specially relevant.

Moreover, Brazilian SMEs are reported to be more opaque and usually depend on relationship banking and collateral loans to access credit, which leads to credit rationing (Zambaldi et al. (2011)). Credit restrictions in Brazil are so severe that in 2017, only about 11 to $19 \%$ of micro and small firms used bank loans ${ }^{1}$ to fund their investments and to obtain cash flow (SEBRAE (2017)). The diagnosis on the type of asymmetric information faced by banks when they finance SMEs in Brazil may be relevant for the design of suitable regulations and policies with the objective of improving their access to the credit market.

Lastly, and more important, there are very few studies assessing the presence of asymmetric information in the Brazilian credit market and, to the best of our knowledge, none of them focuses on firm loans and are able to segregate moral hazard from adverse selection.

An ongoing question in Brazil is why the interest rates practiced in credit markets seem to be abnormally high when compared to peer countries ${ }^{2}$ and

\footnotetext{
${ }^{1}$ The same study reports that only $16 \%$ of SMEs applied for new bank loans in the last 6 months and $82 \%$ reported facing difficulties in this process.

${ }^{2}$ In 2018, World Bank's Interest Rate Spread indicator places Brazil as the second biggest spread (32.2\%), only behind Madagascar (42.6\%).
} 
asymmetric information may play a relevant part in this puzzle ${ }^{3}$. According to Brazilian Central Bank, BACEN, decomposition of the Average Cost Index, default accounts for $37,2 \%$ of the practiced spreads between 2016 and 2018 (BACEN (2018)), and the present analysis can shed some light on default behaviour and its relation with asymmetric information problems.

Our research also relates to the literature that evaluates the effects of changes in creditor protection, based on the assumption that there are asymmetric information in the credit market, either through regulation (L. F. Alencar, Andrade, and Barbosa (2017) and Assunção, Benmelech, and Silva (2014)) or law enforcement (Ponticelli and L. S. Alencar (2016)) transitions.

Our results indicate that moral hazard is a relevant phenomenon in the market under study and its effect is partially attenuated by advantageous selection, indicating that there is, indeed, information asymmetry between BNDES/FGI and the final borrower. A possible explanation for the result of advantageous selection is the existence of intermediary banks' proprietary soft information, unavailable to BNDES/FGI, that allows the banks to better screen the borrowers, offering bigger leverage to lower risk clients.

We also evaluate the usage of risk assessment finding that it seems to be used by intermediary banks in risk based pricing aiming to charge bigger rates without affecting borrowers repayment capacity, but with no evidence that it is used to restrict the leverage the borrower might take.

Lastly, we explore an option of additional leverage funded with nonsubsidized resources that was offered by BNDES for a short period of time to gain further insight into the selection results. Our findings suggest that the advantageous selection is associated with BNDES regular subsidized funding, but with regards to loans funded at market interest rates there is evidence of adverse selection. These results lead us to speculate that a possible explanation for the advantageous selection is that the choice of higher leverage with subsidized loans can indicate a good financial management of the borrower that, later, leads to better repayment outputs.

\section{1}

\section{Asymmetric Information in Credit Markets}

Jaffe and Russel (1976) and J. E. Stiglitz and Weiss (1981) were the first authors ${ }^{4}$ to extend the asymmetric information theory (previously evoked

${ }^{3}$ The main cause studied in the literature is (the lack of) competition (Barbosa, Rocha, and Salazar (2015), Coelho, Mello, and Rezende (2013), Joaquim and Van Doornik (2018) and others).

${ }^{4}$ Earlier, Jaffe and Modigliani (1969) proposed a model in which banks classify borrowing firms into groups based on observable factors, and then determine a single interest rate for 
to explain market failures in other industries, as in Akerlof (1970)) to credit markets ${ }^{5}$ and to relate them to credit rationing. Later, Bester (1987) showed that contracts from a menu of collateral and interest rate ${ }^{6}$ could be used to induce borrowers to reveal their riskiness (or to mitigate risk-taking behavior) leading to market clearing ${ }^{7}$.

Theory following Bester (1987) was labeled "ex ante" in a sense that collateral serves as a device to sort out good and bad borrowers, addressing the ex-ante information gap between borrowers and lenders (adverse selection). Another line, the so-called "ex-post", advocates lenders uses collateral to address ex-post frictions such as moral hazard concerns, difficulties in enforcing contracts and/or costly state verification (see Berger, Frame, and Iannidou (2011) for references on these motivations for collateral requirements).

A distinctive aspect of these earlier theoretical models is that they addressed moral hazard and adverse selection in turns. The first study in the literature to treat both phenomena simultaneously was Chassagnon and Chippori (1997) who presented a model with agents of different levels of unobservable risk and different costs to be induced into high effort, deriving requirements for existence and the nature of possible equilibrium.

The theory of imperfect information motivated several practices in the banking industry such as the use of risk assessment, risk-based pricing, relationship banking and collateral requirements as means to reduce the asymmetric information between lenders and borrowers.

Despite the rapid development of theory related to information problems, the empirical literature started years latter focusing on the automobile market for used cars (Bond (1982) and Genesove (1993)), on automobile insurance (Puelz and Snow (1994) and Chiappori and Salanie (2000)) and on health insurance markets (Altman, Cutler, and Zeckhauser (1998), Cardon and Hendel (2001), Einav, Finkelstein, and Cullen (2010) and Chiappori, Durand, and Geoffard (1998))

The main empirical investigations for the presence of asymmetric information in credit markets focused on credit to households such as credit cards (Ausubel (1999) and Agarwal, Chomsisengphet, and Liu (2010)), home morteach group, which is similar to how risk pricing works. Although the goal of that paper was to theoretically motivate credit rationing, the authors do not address the asymmetric information as the reason why banks are unable to differentiate borrowers, which is precisely the main problem.

${ }^{5}$ Simultaneously, Rothschild and J. Stiglitz (1976) proposed their seminal model of insurance market under perfect competition and asymmetric information.

${ }^{6}$ In J. E. Stiglitz and Weiss (1981), optimal interest rate and collateral are analyzed separately (fixating one at a time).

${ }^{7}$ As long as borrowers wealth is sufficient to pledge collateral in self-selection incentivecompatible financial contracts. 
gage (Hansman (2017) and Edelberg (2004)), home equity credit (Agarwal, Chomsisengphet, and Liu (2015)), subprime automobile loans (Adams, Einav, and Levin (2009) and Einav, Jenkins, and Levin (2012)), personal loans (Karlan and Zinman (2009)) and payday loans (Dobbie and Skiba (2013)).

Otherwise, the empirical investigation of information problems in corporate loan markets is scarcer in the literature, with the following papers worth mentioning.

Toivanen and Cressy (2001) uses a structural approach to test for asymmetric information in loans granted for SMEs in UK. In their model there is only adverse selection, so only collateral is used for screening and their test of asymmetric information comes down to weather (ex-post) low-risk borrowers pledge more collateral, which the authors find no evidence. A drawback of this study is that borrowers (ex-ante) risk assessment is not observed in their data, so their result could be confounded, for example, if risk assessment was used to force a borrower with bad risk assessment to pledge bigger collateral (equivalently a borrower with a good risk assessment was allowed to take an uncollaterized loan) and the risk assessment was a good predictor of ex-post default. In the present study we observe the ex-ante risk assessment.

Berger, Frame, and Iannidou (2011) take information that was recorded in a Bolivian credit registry but not disclosed as private and unobservable to lenders, examining the effect of this information on the use of collateral as a test for adverse selection (the ex-ante theory). Their results suggest that the ex-post theory of collateral (more collateral is demanded for riskier borrowers) is empirically dominant, although the ex-ante theory is also valid for customers with short borrower-lender relation that are relatively unknown to the lender.

Uchida, Uesugi, and Iwaki (2018) explore a quasi-natural experiment of the introduction of non-collateralized loans by a large public bank in Japan to assess the presence of adverse selection and moral hazard, finding that only the latter seem to be present. Their market is similar to ours, loans to SMEs from a public bank. As Uchida, Uesugi, and Iwaki (2018) points out, since public banks' credit lines are "shelf" product and there is no bargaining on the loan conditions, we can assume that the choices regarding the contract (in our case the leverage and the size of the loan) are made by the borrower, targeting to maximize its expected profit/utility.

Wang (2005) argues that the traditional estimation of the correlation between loan size and default, without accounting for banks' response trying to avoid default when a payment is late, pools the effects of pure moral hazard and collection intensity. To identify pure moral hazard, he observes that banks response should not influence the decision to delay payments, but it could 
influence the decision to default. Based on this analysis, the author study Chinese loans to households, finding evidence of moral hazard whose effects on default are reduced by lender's collection intensity.

We do not have data on late payment (we observe only when default is effectively reported), however, we believe this should not be a concern since it is reasonable that, if there is some variation on collecting intensity ${ }^{8}$, it may be in the direction that larger loans lead to more aggressive collection which would, if present, bias toward underestimating the effects of moral hazard (considering that it would prevent borrowers to default on bigger loans).

To isolate moral hazard effects, Wang (2005) address possible concerns of endogeneity relying on randomly assignment of clients to loan officers. A caveat of this strategy is that, as reported by the author, several soft (uncoded) information are used by loan officers to decide and there is no guarantee that the variation, explored for identification, comes from loan officers idiosyncrasies rather than from these information that are not observed by the econometrician. In our study, we rather explore horizontal variation on BNDES policies that are credibly independent of unobserved information on individual borrowers.

Also, following the technique from Adams, Einav, and Levin (2009), Wang (2005) finds a possible evidence of advantageous selection, but is unable to analyze if this result may come from effective underwriting by the lender ${ }^{9}$. This incapacity comes from the fact that in their setting the loan office determines the loan size on its own (the interest rate and term are fixed), it is not a choice of the borrower. In our setting, we assume that the bank sets the interest rate coupled with a restriction on the maximum leverage, leading the decision on the size of the loan to the borrower in a non-bargaining framework. In our setting we find evidence of advantageous selection that is not to be confused with banks underwriting capacity.

Finally, there are a few studies investigating information asymmetry problems in Brazilian credit markets. As anticipated, to our notice, this is the first study designed to directly identify the presence of information problems in the Brazilian credit market of corporate loans and able to separate moral hazard from adverse selection.

De Lucinda and Vieira (2014) study Brazilian credit card market exploring a randomization in new-credit offers to access demand sensitivity to interest rates and find evidences of adverse selection in the extensive margin

${ }^{8}$ Collection after default is regulated by the FGI statute, so it should be expected to be fairly homogeneous across intermediaries and loans.

${ }^{9}$ The positive correlation could be due to safer borrowers demanding larger loans or effective underwriting mechanisms leading to good matches. 
(i.e., acceptance of the offer), but not in the intensive margin (i.e., how much credit to take) ${ }^{10}$. Since credit conditions were randomized, i.e., they were not based on banks perception of specific borrower risk, their study evaluate riskiness using banks' own measure of risk ${ }^{11}$ and not on default. In our framework, pricing comes from an assessment of risk, so adverse selection is defined as a selection problem not captured by the credit score.

Fontes (2012) uses an empirical approach similar to ours (based on Adams, Einav, and Levin (2009)) to analyze the presence of moral hazard and adverse selection on consumer loans for household appliance. Her contractual setting is different from the one presently studied since borrowers chose between a interest rate/term menu of loans, but not the down payment, and her identification strategy is based on exogenous special offer periods. She finds a prevalent causal component, similar to our definition of moral hazard, of contract choice (specially the interest rate) on default behavior.

Two other studies indirectly find evidence of information problems in Brazilian markets: Sacramento Junior (2017) evaluates the effects of a (downward) change ${ }^{12}$ in the threshold of loans that are reported to Brazilian Central Bank, which allowed financial institutions to access larger credit histories of MSE. He registers that the increase in available information benefited borrowers who obtained more loans under smaller interest rates. Lucente (2014) reports that longer relationship between the firm and the borrower leads to bigger and cheaper loans, which indicates that there is an information gap that is lowered as the relationships extends (and that this effect is bigger than the implicit market power from private information ${ }^{13}$ ).

This kind of indirect evidence of asymmetric information is similar to Gonas, Highfield, and Mullineaux (2004) and Berger, Espinosa-Vega, et al. (2011). As Berger, Frame, and Iannidou (2011) points out, while these studies succeed in identifying a variation in the information environment, they do not access directly the information available before and after which would be necessary to evaluate the presence of selection effects. In our study we observe all the information available to BNDES and FGI, taking their perspective when discussing information asymmetries with regards to the final borrowers.

\footnotetext{
${ }^{10}$ Authors justify that the low rate of acceptance could explain this poor identification.

${ }^{11}$ Defined as selection on observables by Ausubel (1999).

${ }^{12}$ Until April 2012, banks were required to report to the Brazilian credit registry only total loans above $\mathrm{R} \$ 5,000$, afterwards this threshold was reduced to $\mathrm{R} \$ 1,000$.

${ }^{13}$ See Berger, Frame, and Iannidou (2011) for a comment on the ambiguous relation between relationship banking and asymmetric information.
} 


\section{2}

\section{Sources of Identification}

As in Adams, Einav, and Levin (2009), we define adverse selection as the situation where observably identical borrowers, due to unobservable heterogeneities in preferences and risk, choose different loans and the one who chooses the bigger loan defaults more. Also, as in Adams, Einav, and Levin (2009), we define moral hazard as the theoretical situation when the same individual by taking a bigger loan is more prone to default.

Both phenomena manifest through a positive correlation between loan size and ex-post default, which could be tested using the technique in Chiappori and Salanie (2000). However, this result would be mixing adverse selection and moral hazard, and the main empirical challenge in the present study is to separately identify these two phenomenon.

To do so, we adapt the strategy in Adams, Einav, and Levin (2009) to separate moral hazard from adverse selection based on a specificity of BNDES credit granting process: each credit line establishes a maximum percentage of the investment that could be financed, in a literal translation, the maximum participation, or, as we will often call, the maximum leverage. This policy sets a restriction on borrowers' choice on the size of the loan, or equivalently, on the leverage of the project.

To avoid manipulations in the value of the investment by the borrower (circumventing the leverage limit), BNDES policies establishes that all the expenses with the project must be verified by the intermediary bank and BNDES performs aleatory auditions on borrowers and intermediary banks to certify correct procedures.

Hence, BNDES horizontal changes over time in the maximum participation policy, credibly independent from the pool of borrowers, can be used as instruments creating the experimental variation necessary to attain separation of moral hazard and adverse selection.

Identification of moral hazard comes from the situation where two identical borrowers are subjected to different maximum leverage limits and (at least) one of them is binded. This borrower gets a loan that is smaller than he would optimally chose and smaller than the other identical borrower with bigger maximum leverage limit. Then, if the borrower with restricted smaller 
loan default less, we would have evidence of moral hazard, that is, the increase in default that are caused merely by taking a bigger loan.

We also estimate a loan demand as a first step in the empirical model. Identification of the credit demand relies on horizontal changes on the credit conditions offered by BNDES. Traditional econometric theory states that, in a simultaneous equation setting of demand and supply, we can identify demand when we have shifts on the supply that are exogenous from the demand's perspective.

From 2011 to 2018, BNDES has presented several changes in its credit policies that affected all of its credit lines ${ }^{1}$, which makes this period under study specially suitable for demand identification. Table (2.1) summarizes these horizontal reforms in credit conditions:

Table 2.1: Reforms in BNDES credit conditions

\begin{tabular}{ccc}
\hline Reform & $\begin{array}{c}\text { Time } \\
\text { Coverage }\end{array}$ & Changes \\
\hline- & $2011-2014$ & baseline \\
2015 & $12 / 2014-12 / 2015$ & - participation and cost \\
2016 & $12 / 2015-12 / 2016$ & - participation and cost \\
2017 & $12 / 2016-11 / 2017$ & - participation and cost \\
& & - clients size classification \\
$2017 / 2018$ & $11 / 2017-03 / 2018$ & - base funding change $($ TLP) \\
2018 & $03 / 2018-$ - Today & - participation and cost \\
\hline
\end{tabular}

Since BNDES is a state-owned bank, its credit/lending policies are mainly subjected to the governmental economic orientation and may be assumed, on a micro level, as exogenous to the performance of specific credit lines such as the ones supported by FGI.

Table (2.2), registers p-values for the test of difference of means between loans contracted 3 months before and 3 months after the credit reforms indicated in Table (2.1), each one referred as a separate time-"window" 2 . It can be noticed that the mean total investment and default output seem to

\footnotetext{
${ }^{1}$ BNDES makes distinctions between lines (mid term credit policies with specific objectives), products (permanent credit instruments) and programs (short term credit policies with specific objectives) that are not relevant in this study's perspective.

${ }^{2}$ The reform from nov/2017 to mar/2018 has a very short "after" period with very few new loans. Hence we compare loans before this reform with loans after the last reform (after mar/2018), in the so-called "window 4".
} 
be equal ${ }^{3}$ around all these credit reforms, corroborating the hypothesis that these credit reforms do not alter the pool of the borrowers.

Table 2.2: Test for the equality of means between loans granted in three months window around credit reforms

p-value for the test of equal means

\begin{tabular}{lcc}
\hline & Incidence of default & Total Investment \\
Window 1 & $34 \%$ & $87 \%$ \\
Window 2 & $40 \%$ & $20 \%$ \\
Window 3 & $36 \%$ & $11 \%$ \\
Window 4 & $18 \%$ & $33 \%$ \\
\hline
\end{tabular}

Notice that reforms in Table (2.1) regularly changed the maximum participation and the base (not risk-related) interest rate, and one of them altered the maximum grace and amortization terms of the loans. The changes in the maximum participation will be essential for accurate identification of moral hazard based on the strategy previously introduced. Changes on credit conditions will be essential for the identification elasticities in the estimation of credit demand.

Table (2.3) exemplifies some of these changes in two BNDES credit lines (Finame BK Aquisiçao and Automatico MPME) that were supported by the FGI throughout the period:

Table 2.3: Example of changes in BNDES credit lines

\begin{tabular}{|c|c|c|c|c|c|c|}
\hline & 2011 & 2015 & 2016 & $2017^{1}$ & $2017 / 2018$ & 2018 \\
\hline & \multicolumn{6}{|c|}{ BNDES Finame BK Aquisição } \\
\hline Funding & TJLP & TJLP & TJLP & TJLP & TLP & TLP \\
\hline Maximum Participation & $90 \%$ & $70 \%^{2}$ & $80 \%$ & $80 \%$ & $100 \%$ & $100 \%$ \\
\hline \multirow[t]{2}{*}{ Basic spread } & - & $+0,6 \%$ & - & $+0,2 \%$ & - & $-0,43 \%$ \\
\hline & \multicolumn{6}{|c|}{ BNDES Automatico MPME } \\
\hline Funding & TJLP & TJLP & TJLP & TJLP & TLP & TLP \\
\hline Maximum Participation & $90 \%$ & $70 \%^{2}$ & $80 \%$ & $80 \%$ & $80 \%$ & $100 \%$ \\
\hline Basic spread & - & $+0,6 \%$ & - & $+0,2 \%$ & - & $-0,43 \%$ \\
\hline
\end{tabular}

Notice that the tablenotes identify a period when BNDES offered borrowers what we call an "enhancement option". When this option was available,

${ }^{3}$ There is no p-value below a $10 \%$ confidence cut-off to dismiss the null hypothesis of equal means. 
the borrower could opt to extend the leverage of the project above the maximum participation by taking a loan fully funded on market standard cost (i.e. a higher interest rate without BNDES subsidized base cost). We will later explore this option to gain further insights on the selection phenomenon. 


\section{Data}

The data from BNDES come from two main databases (internally called Universes), the OPE, which contains detailed information on loan contractual conditions, and the FIN which have data on default (only accessible to FGI administrative team).

The database contains a cross-section of 15,227 indirect credit operations from BNDES that were secured by FGI.

Indirect operations are loans where BNDES provides the resources (the funding), a financial intermediary pass along the loan and bears its risk before BNDES, in exchange charging a spread over the interest rate of BNDES credit line.

FGI ${ }^{1}$ is a contractible credit insurance designed to enhance the credit assessment of loans taken by SMEs. It covers $10 \%$ to $80 \%$ of the total loan and supports operation with risk rating, assessed by the intermediary bank (disconsidering the FGI guarantee), from "AA" to "D" (in the scale according to Resolution $\mathrm{n}^{\mathrm{O}}$ 2.682 from 21.12.1999 Conselho Monetario Nacional-CMN). The FGI support can be solicited by firms whose annual revenue is up to $R \$$ 300 millions ${ }^{2}$.

FGI works as a on first demand credit guarantee that can be claimed 90 days after the delinquency occurred and once the insured bank has initiated the collection procedures established in the FGI policies. We use the delinquency notification to the FGI as the event of default.

We study indirect operations that were secured by the FGI mainly because these operations have available information on default ${ }^{3}$ and because the FGI policies (coupled with BNDES credit line policies) set certain standards that make these operations comparable.

For example, the insured (end-of-the-line borrower) is obligated to constitute minimum counter guarantees to the FGI (mainly the guaranty from the controlling partner and/or the fiduciary property of the asset being acquired

\footnotetext{
${ }^{1}$ For futher detail on FGI consult https : //www. bndes.gov.br/wps/portal/site/home/ financiamento/bndes-fgi/bndes-fgi and Lanz, Perufo, and Mantese (2014)

${ }^{2}$ The FGI can also support loans from individual entrepreneurs, a type of firm with a single employee/owner.

${ }^{3}$ Usually BNDES does not have data on default of the final loan since the intermediary bank takes this risk before BNDES and this is an information protected by banking secrecy.
} 
that are persecuted by the insurer after honoring a defaulted payment). Only specific BNDES credit lines can be supported and just financial institutions that are licensed may operate with it.

The sample covers from the first operations supported by FGI in 2009 to newest operations that had their first capital payment ${ }^{4}$ due up to june/ $2019^{5}$.

The sample has only operations whose purpose is to support investment, so a large number of working capital loans supported by FGI were excluded from the sample. This choice was made because of two reasons: first, to assure comparability between the loans; second, because BNDES maximum participation rule, essential in the identification strategy, is only applicable to investment-purpose loans.

Due to normative and statutory restrictions, only FGI team could directly handle data regarding default. So the study was conducted in a way that the data set with relevant information and the coding was handled to the FGI team, who inputted default data, ran the regression and send back the results.

The FGI management team described that in some occasions intermediary(ies) did not report default due to internal reasons (technology integration or risk policies). This behaviour by specific intermediaries was clearly identified the FGI team and, based on conversation with the parties, it does not seem to be endogenously related with bank-specific loan's demand or default pattern. This missing data problem is a limitation of the database and to mitigate the problem it was asked for the FGI team to exclude from the dataset all the operations from intermediary(ies) that never presented any claim. This means that the dataset may include operations that defaulted in a period of time that the intermediary was unable to report which would otherwise increase the incidence of default in the sample. However, as explained by FGI team, in most of these situations defaults were later reported by the intermediary, so it was mostly a matter of timing ${ }^{6}$ not underreporting. Either way, during the analysis we assume that this eventual missing data problem was uncorrelated to the underlying phenomena under study.

As it can be seen on Table 3.1, the sample is concentrated, both in value and in quantity, on loans to micro firms with risk assessment primarily above $\mathrm{C}$ in CMN scale. Size is defined following a criteria set by BNDES based on total annual revenue of the firm.

\footnotetext{
${ }^{4}$ We define this cut-off to exclude loans that had not began their repayment schedule.

${ }^{5}$ Since default data covers delinquency notifications received by FGI up to july/2019 and banks present claims with a one month of delay.

${ }^{6}$ This affects the due payments that the intermediary is able to recover since FGI policies sets time deadlines for claims.
} 
Table 3.1: Sample division by risk rating and borrowers' size

Borrower's Size Risk Rating Obs. \% Sample \% Value Loans

\begin{tabular}{lllcc} 
MEDIUM & AA & 351 & $2.3 \%$ & $3.7 \%$ \\
SMALL & AA & 401 & $2.6 \%$ & $3.8 \%$ \\
MICRO & AA & 3373 & $22.1 \%$ & $15.4 \%$ \\
MEDIUM & $\mathrm{A}$ & 333 & $2.2 \%$ & $6.8 \%$ \\
SMALL & $\mathrm{A}$ & 227 & $1.5 \%$ & $3.1 \%$ \\
MICRO & $\mathrm{A}$ & 3085 & $20.3 \%$ & $13.9 \%$ \\
MEDIUM & $\mathrm{B}$ & 508 & $3.3 \%$ & $9.3 \%$ \\
SMALL & $\mathrm{B}$ & 543 & $3.6 \%$ & $5.5 \%$ \\
MICRO & $\mathrm{B}$ & 3678 & $24.2 \%$ & $19.3 \%$ \\
MEDIUM & $\mathrm{C}$ & 320 & $2.1 \%$ & $5.0 \%$ \\
SMALL & $\mathrm{C}$ & 462 & $3.0 \%$ & $4.2 \%$ \\
MICRO & $\mathrm{C}$ & 1946 & $12.8 \%$ & $10.0 \%$ \\
\hline
\end{tabular}

The loans in the sample were originated by nineteen different financial institutions authorized to contract BNDES indirect loans and to operate with FGI. On average each intermediary originated 801 loans with a standard deviation of 1,326 and median of 359. We control for intermediary in the regressions, but due to banking secrecy we cannot show further details on this aspect of the data.

Table 3.2 presents descriptive statistics of the key quantitative variables used in the empirical setting: 


\section{Table 3.2: Descriptive Statistics from the sample}

Table reports descriptive statics from a sample of BNDES indirect loans for investment of SMEs. Match Fund stands for Matching Fund, i.e. the amount of the investment that was funded with borrower's own resources. Max Part is the maximum allowable leverage set by BNDES credit policy. Enhance Y.N. is a dummy indicating whether the borrower took (1) additional leverage funded in market cost when this option was available. Grace stand for grace period. Amort stand for amortization period. Interest is the interest rate of the loan. I_Default is a dummy indicating whether the loan defaulted (1) or not (0). Perc_Pay is the fraction of the loan principal payments made up to the time when the sample was constructed (june/2019).

Sample size $=15,227$

Statistics

\begin{tabular}{|c|c|c|c|c|c|c|}
\hline Variables & Mean & St. Dev. & Min & Q1 & Q3 & Max \\
\hline Loan $(\mathrm{R} \$ 1 \mathrm{~K})$ & 249.79 & 434.41 & 1.21 & 104.04 & 279.63 & $14,578.17$ \\
\hline Match Fund ( $\mathrm{R} \$ 1 \mathrm{~K})$ & 51.95 & 145.93 & 0.00 & 8.39 & 62.70 & $7,149.84$ \\
\hline Leverage $\%$ & 83.06 & 12.94 & 11 & 79 & 90 & 100 \\
\hline Max Part \% & 95.37 & 8.17 & 70 & 90 & 100 & 100 \\
\hline Enhance Y.N. & $5.0 \%$ & 0.217 & - & - & - & - \\
\hline Grace (months) & 5.41 & 4.25 & 0 & 3 & 6 & 42 \\
\hline Amort (months) & 68.30 & 21.28 & 9 & 57 & 90 & 216 \\
\hline Interest $(\% / \mathrm{yr})$ & 6.14 & 3.21 & 2.50 & 4.00 & 7.00 & 22.79 \\
\hline Interest-Selic $(\% / y r)$ & -4.25 & 2.77 & -7.75 & -5.50 & -4.25 & 12.27 \\
\hline I_Default & $13.7 \%$ & 0.34 & - & - & - & - \\
\hline Perc_Pay \% & 74.6 & 30.0 & 0.9 & 55.2 & 100 & 100 \\
\hline
\end{tabular}

Notice the sample mainly consist of loans below $\mathrm{R} \$ 280 \mathrm{k}^{7}$ with substantial variance. As expected the leverage is always below the maximum leverage authorized by BNDES credit policies (on average $83 \%$ and 95\%, respectively) with $33.15 \%$ of the loans in the sample (5.049) reflecting the maximum allowed participation.

As anticipated, for some period, BNDES offered to the borrower the option to get a loan over the maximum participation as long as this amount was totally funded on market cost (at this time BNDES funded all its loans in TJLP, an interest rate lower than the base interest rate of the economy). This decision, labeled "Enhance Y.N.", will be explored at the end of this article to provide further insight on the selection effect found on the base model. For

${ }^{7} 65 \mathrm{~K}$ U\$ on feb/2020 exchange rate. 
now, we can point out that $5 \%$ of the sample chose to take this enhancement option, but this choice was only available to a much smaller subsample as shown ahead on Section 7.

As it can be seen, the loans in the sample can be considered long term for Brazilian standards with, on average, a grace period (when only interest is due) around 5 months and an amortization period of over 68 months (5 years and 8 months), both of those terms with sizable variability.

The interest rate of the contracts presents considerable variation from as low as $2.5 \%$ to $22.79 \%$ per year. On average the interest rate is below the Brazilian base rate by 425 bps, which evidences that these loans conditions can be considered favorable for Brazilian standards.

As Toivanen and Cressy (2001), we define a 'default' when the entrepreneur (firm) has failed to pay interest or capital on the loan as it falls due, regardless if it is the consequence of a renegotiation or if it goes 'into recoveries' (when the loan is accelerated and the guarantees are executed and usually a legal process is initiated to recover the loan). In the sample there is a default rate of $13.7 \%$. At the time cut-off we used to define the sample, there were loans at very different stages (defaulted or not) of payment, most (42\%) of them were fully paid.

Borrowers' sector identifications (Classificacão Nacional de Atividades - CNAE) were also available and we tested including fixed effects for them on demand and default regression which were not significant nor changed the result (in size and significance) for the key variables. Since CNAE has a large number of categories (most of those without any default), due to dimensionality impediments in the Tobit setting, we will not include CNAE FE on the empirical specification.

Figures (3.1(a)) and (3.1(b)) show at which stage default happened in the sample, sorted by the ex-ante risk-assessment and the size of the borrower: 


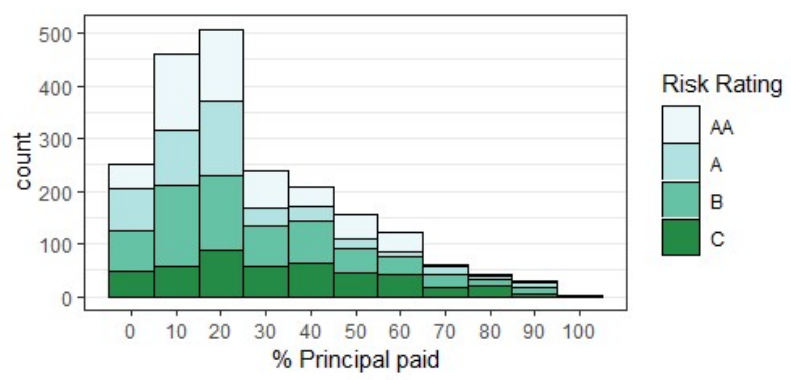

(3.1(a)) by risk type

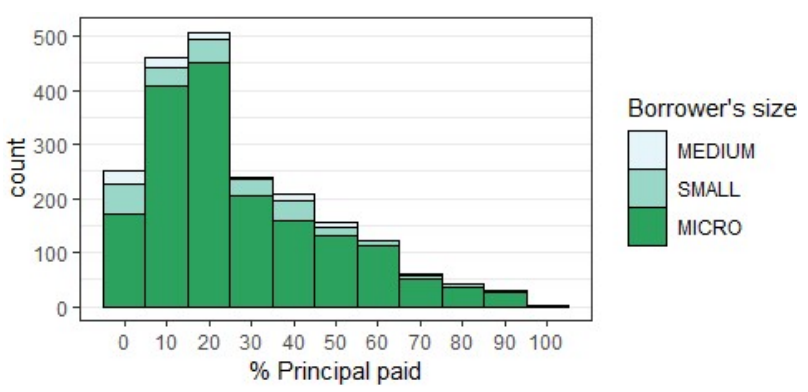

(3.1(b)) by borrower's size

Figure 3.1: Histograms of \% Payed before Default

It is worth noticing that most of the defaults in the sample occurs before the $30 \%$ mark of loan's repayment, gradually reducing after that point.

Considering that risk assessment categories are similarly distributed (AA is $27 \%$ of the sample, $\mathrm{A}$ is $24 \%, \mathrm{~B}$ is $31 \%$ and $\mathrm{C}$ is $18 \%$ ), Figure (3.1(a)) indicates that they may not to be good predictors of default, a point that will be explored further in Section 5.1.

We conclude this section with a graphical motivation of the key findings in this study. First, Figure (3.2) displays the percentage of defaulted loans in each $10 \%$ leverage range. The evidence that default is more common in loans with higher leverage suggests that the combined effect of moral hazard and selection on leverage choice is negative.

Secondly, Figure (3.3) compares the percentage of defaulted loans in the leverage category that was freely (tones of blue) ${ }^{8}$ chosen with the ones that were limited by the maximum participation (tones of green). There is evidence that default events on loans whose leverage was restricted are less frequent than on the ones whose leverage was freely chosen. This observation suggests the presence of advantageous selection, i.e. the ones that wanted to take a bigger loans, but were restricted, default less than the ones with the same leverage that satisfied their intention.

${ }^{8}$ Leverages below $70 \%$ were never restricted by BNDES maximum participation policies, so we do not include them in Figure (3.3) that displays only leverage ranges in which there were censored and uncensored loans. 


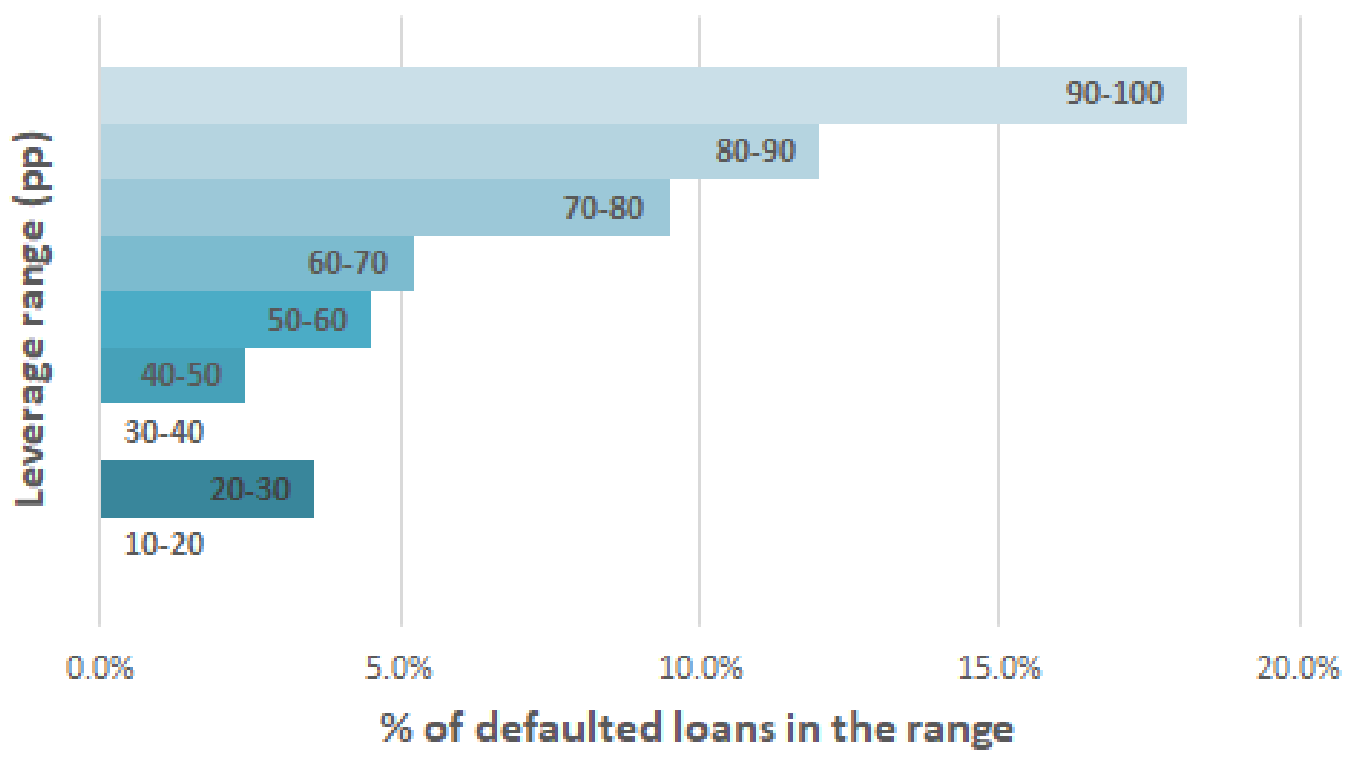

Figure 3.2: \% of defaulted loans by leverage range

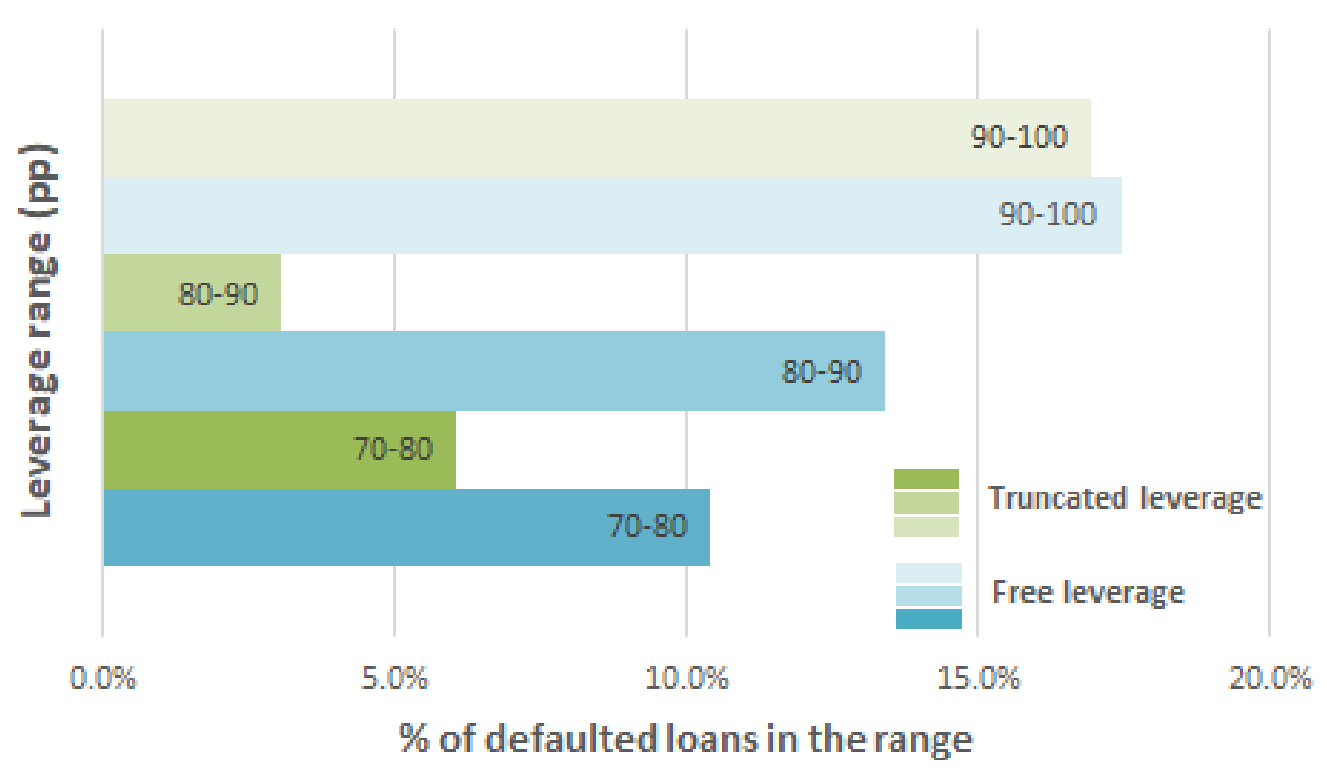

Figure 3.3: \% of defaulted loans in restricted and unrestricted leverage ranges 


\section{4}

\section{Empirical Approach}

Since credit operations are originated by intermediary banks, BNDES lacks data on applications to assess the firm's decision to take a loan/project (the extensive margin $)^{1}$. So our empirical setting starts with the borrowers' decision on the size of the loan (the intensive margin), after the decision to make the investment and finance part of it has been made by the firm.

We adopt a proxy for credit demand slightly different from Adams, Einav, and Levin (2009), that used loan size. When we use the loan size as the key regressor in the default regression to look for asymmetric information problems, there is the concern that this variable, usually highly correlated with the value of the investment (when the choice is the maximum participation it is an exact $\%$ of it), may also be capturing the effect of collateral value on default ${ }^{2}$. Hence, we rather introduce the Total Investment in the Default Regression as a control variable to proxy for collateral value and to avoid confounding effects (i.e. multicolinearity concerns) with the loan size variable, we use the leverage (i.e. the total investment divided by the loan) as the key credit choice .

Notice that the interpretation of the results is exactly the same if we have used the loan size ${ }^{3}$, but we believe it is more reliable to assume leverage to be orthogonal to the investment value and that it is a more adequate demand variable from BNDES loans.

As anticipated, BNDES sets a restriction of a maximum allowable participation and borrowers who commit to a larger matching fund, or a smaller leverage, may receive from banks a lower interest rate in return. Hence, to model the loan size decision, which we call the credit demand, following Adams,

\footnotetext{
${ }^{1}$ And related inefficiencies such as credit rationing and lemon markets problem cannot also be accessed.

${ }^{2}$ This effect may be in the opposite direction of moral hazard, since collateral can be assumed to mitigate strategic default.

${ }^{3}$ We also run the models with loan size in the specification and results were significant and with identical interpretation.
} 
Einav, and Levin (2009), we specify the following Tobit model ${ }^{4}$ :

$$
L_{i}= \begin{cases}L_{i}^{*}=x_{i}^{\prime} \beta_{D}+\varepsilon_{i} & \text { if } L_{i}^{*} \leq \overline{L_{i}} \\ \overline{L_{i}} & \text { if } L_{i}^{*}>\overline{L_{i}}\end{cases}
$$

Where $x_{i}$ contains loan conditions (interest rate, grace and amortization terms) and control variables such as the credit category, borrower's size, the project (or investment) total cost $\left(p_{i}\right)$ and fixed effects for year, month and intermediary bank. $\overline{L_{i}}$ is the maximum allowable leverage and $\varepsilon_{i} \stackrel{i i d}{\sim} N(0, \sigma)$ is the firm's idiosyncrasy (i.e., a hidden motive towards demanding a bigger loan) or the Tobit residual.

As anticipated, we assume that $p_{i}$, the project cost or the total investment, is exogenous from the perspective of the credit demand, based on BNDES controls to avoid manipulations in this value by the borrower.

The next step is to model the loan repayment or default behavior. As in Adams, Einav, and Levin (2009), a reasonable modeling choice is a Cox proportional hazards model that allows a flexible default pattern over time and circumvents censoring problem. Thus the probability of default at $t$ given that the loan is still active is specified as:

$$
h\left(t \mid L_{i}, x_{i}\right)=\exp \left(L_{i} \delta_{L}+x_{i}^{\prime} \delta_{x}\right) h_{0}(t)
$$

Where $h_{0}(t)$ is the baseline hazard, an arbitrary (non parametric) function ${ }^{5}$, and $t$ is the fraction of the loan payments made, which we choose as in Adams, Einav, and Levin (2009) to overcome differences in the terms of different loans.

While the Cox model can accommodate censoring it requires the assumption that changes in the proportional hazard shift the baseline multiplicatively and have no other impact on the baseline hazard. This assumption is not present in a linear probability model or probit or logit, which we use as alternative specifications for the default regression to perform a robustness test of the results.

The default model addresses the central empirical implication of the theory of asymmetric information: the relationship between default and leverage choice. Both moral hazard and adverse selection imply a positive cross-sectional correlation between these variables, conditional on priced characteristics.

\footnotetext{
${ }^{4}$ A stylized fact confirmed in the sample is that a large portion of borrowers chose exactly the maximum allowable leverage.

${ }^{5}$ Cox proportional hazards model is estimated using a partial likelihood approach that disregard the estimation of the baseline hazard. We only take the base hazard for our simplistic exercise on spreads' sizing in Section 6.4, using the prediction-at-the-means baseline hazard.
} 
The main obstacle is to separately identify these two effects. Without further development, the estimation of Equation (4-2) would pool in the estimated coefficient of leverage the causal effect of having a larger loan on the probability of default (i.e., moral hazard) with the correlation induced by observably equivalent borrowers, who, nevertheless, have different risks and took different loans (i.e., adverse selection).

The separate identification of moral hazard and adverse selection in Equation (4-2) comes from an exclusion restriction. The key assumption is that, conditional on all relevant variables, repayment behavior depends on the leverage, but not directly on the maximum participation, which matters only insofar as it influences the leverage choice (or equivalently the size of the matching fund).

Then, to attain separability, we use a two-stage control function (suggested by Train (2003)), including the estimated residual from the loan demand model as a control variable in the default model. We define the loan demand residual for individual i as:

$$
\zeta_{i}= \begin{cases}L_{i}-x_{i}^{\prime} \widehat{\beta}_{D} & \text { if } L_{i}<\overline{L_{i}} \\ E\left[\varepsilon_{i} \mid \varepsilon_{i} \geq \overline{L_{i}}-x_{i}^{\prime} \widehat{\beta}_{D}\right] & \text { if } L_{i}=\overline{L_{i}}\end{cases}
$$

The constructed residual $\zeta_{i}$ contains the borrower's private information related to the choice of the leverage, the idiosyncrasy that leads the firm to demand bigger loans. After including it in the estimation of the default equation, as well as the other observed covariates, the remaining variation in leverage is due entirely to variation in the maximum participation, which is exogenous, thus providing the experimental variation to test for the presence of moral hazard.

In other words: conditional on the chosen leverage, borrower's matching fund is sunk, so it should not directly affect default. But it should also reflect all the buyer's relevant information about default at the time of the purchase. Therefore, a positive correlation between the loan demand residual and the probability of default, conditional on leverage and observed characteristics, indicates that a borrower who chooses a bigger leverage for unobservable reasons is more likely to default later for unobservable reasons, which is precisely the notion of adverse selection arising from asymmetric information about default risk. Hence, we can quantify the adverse selection by the difference in the coefficient of leverage in the default rate equation when $\zeta$ is omitted (thus pooling moral hazard and adverse selection) with the estimated coefficient including $\zeta$ (reflecting solely the moral hazard effect).

Notice that, as in Adams, Einav, and Levin (2009), our definition of 
adverse selection does not concern with the underlying process leading to the observed behaviour, which could happen because forward-looking agents anticipate a high likelihood of default and accordingly do not commit to large down payments, or because firms who are illiquid today and unable to make sizeable down payments are also likely to be illiquid later and have trouble with repayment. This also applies to the definition of moral hazard that could be related either to a behavioral motivation, a deliberate/strategic default, or to merely uncontrollable reasons. From the standpoint of banks informational problem, these motivations are not relevant.

In practice, the use of credit scoring allows banks to partially discriminate borrowers based on observable risk predictors. If banks could distinguish perfectly between risk types and price accordingly, we should expect that lowrisk customers take bigger leverage than high-risk once credit scoring is being used, relatively to self-selection that occurs given a common set of choices (without credit scoring). More generally, in the presence of credit scoring, the correlation between leverage and default rate will be lower if one does not condition on risk group than if one does.

Hence, the technique used to separate the effects of moral hazard and adverse selection can be extended to evaluate the benefits of risk-assessment. To do so, we exclude the controls for credit category in Equation (4-2) and evaluate the change in the coefficient of the leverage, expecting that the use of risk-based pricing should lower the cross-sectional correlation between leverage and default. 
5

\section{Results}

\section{1}

\section{Loan Demand Regression}

Table (5.1) registers the loan demand as defined in Equation (4-1) with Leverage as the dependent variable under two different specifications (with or without the Selic interest rate) both with and without fixed effects factor for Intermediary Banks. 


\section{Table 5.1: Credit demand regression}

Table reports Tobit regression estimates of Equation (4-1). Leverage in percentage point is the dependent variable. Small and Micro dummies for firm's size are reported with Medium size the reference category. Risk assessment dummies are reported with the best rating, AA-rating, as the reference category. Grace stands for the grace period in months. Amort stands for the amortization period in months. Enhance Y.N. is a dummy variable taking the value of 1 if the borrower opted to take a leverage beyond the maximum participation funded at market cost and 0 otherwise. Total Investment is the project's total cost. Scale is the standard deviation of Tobit idiosyncratic error. Specification (2) differs from specification (1) by the inclusion of Brazilian base interest rate, the Selic. All models have month and year fixed effects and each specification is presented with and without intermediary bank fixed effects

\begin{tabular}{|c|c|c|c|c|}
\hline & \multicolumn{4}{|c|}{ Leverage } \\
\hline & $(1)$ & $(1: \mathrm{FE})$ & $(2)$ & $(2: \mathrm{FE})$ \\
\hline (Constant) & $\begin{array}{l}12.293^{* * *} \\
(2.970)\end{array}$ & $\begin{array}{c}4.209 \\
(17.601)\end{array}$ & $\begin{array}{c}3.468 \\
(5.221)\end{array}$ & $\begin{array}{l}-6.263 \\
(18.501)\end{array}$ \\
\hline SizeSMALL & $\begin{array}{c}-4.016^{* * *} \\
(0.621)\end{array}$ & $\begin{array}{c}-3.366^{* * *} \\
(0.608)\end{array}$ & $\begin{array}{c}-4.017^{* * *} \\
(0.620)\end{array}$ & $\begin{array}{c}-3.379^{* * *} \\
(0.608)\end{array}$ \\
\hline SizeMICRO & $\begin{array}{c}-13.604^{* * *} \\
(0.544)\end{array}$ & $\begin{array}{c}-9.739^{* * *} \\
(0.561)\end{array}$ & $\begin{array}{c}-13.618^{* * *} \\
(0.544)\end{array}$ & $\begin{array}{c}-9.781^{* * *} \\
(0.561)\end{array}$ \\
\hline Risk rating $\mathrm{A}$ & $\begin{array}{c}-3.807^{* * *} \\
(0.397)\end{array}$ & $\begin{array}{l}1.660^{* * *} \\
(0.535)\end{array}$ & $\begin{array}{c}-3.777^{* * *} \\
(0.398)\end{array}$ & $\begin{array}{l}1.681^{\text {*** }} \\
(0.535)\end{array}$ \\
\hline Risk rating $B$ & $\begin{array}{c}-2.648^{* * *} \\
(0.355)\end{array}$ & $\begin{array}{l}2.789^{* * *} \\
(0.442)\end{array}$ & $\begin{array}{c}-2.601^{* * *} \\
(0.356)\end{array}$ & $\begin{array}{l}2.833^{* * *} \\
(0.443)\end{array}$ \\
\hline Risk rating $\mathrm{C}$ & $\begin{array}{c}-1.762^{* * *} \\
(0.397)\end{array}$ & $\begin{array}{l}2.891^{* * *} \\
(0.518)\end{array}$ & $\begin{array}{c}-1.697^{* * *} \\
(0.399)\end{array}$ & $\begin{array}{l}2.951^{* * *} \\
(0.520)\end{array}$ \\
\hline $\log$ (Grace) & $\begin{array}{l}1.234^{* * *} \\
(0.351)\end{array}$ & $\begin{array}{c}-0.340 \\
(0.327)\end{array}$ & $\begin{array}{l}1.196^{* * *} \\
(0.352)\end{array}$ & $\begin{array}{l}-0.393 \\
(0.333)\end{array}$ \\
\hline $\log$ (Amort) & $\begin{array}{l}23.958^{* * *} \\
(0.649)\end{array}$ & $\begin{array}{l}21.225^{* * *} \\
(0.878)\end{array}$ & $\begin{array}{l}24.001^{* * *} \\
(0.649)\end{array}$ & $\begin{array}{l}21.225^{* * *} \\
(0.878)\end{array}$ \\
\hline $\log ($ Interest $)$ & $\begin{array}{c}-2.449^{* * *} \\
(0.588)\end{array}$ & $\begin{array}{c}-1.551^{* *} \\
(0.591)\end{array}$ & $\begin{array}{c}-3.458^{* * *} \\
(0.841)\end{array}$ & $\begin{array}{c}-2.751^{* * *} \\
(0.869)\end{array}$ \\
\hline Enhance.Y.N. & $\begin{array}{l}14.188^{* * *} \\
(0.864)\end{array}$ & $\begin{array}{l}15.499^{* * *} \\
(0.891)\end{array}$ & $\begin{array}{l}14.315^{* * *} \\
(0.869)\end{array}$ & $\begin{array}{l}15.624^{* * *} \\
(0.896)\end{array}$ \\
\hline $\log ($ Total Investment) & $\begin{array}{c}-1.817^{* * *} \\
(0.172)\end{array}$ & $\begin{array}{c}-1.923^{* * *} \\
(0.170)\end{array}$ & $\begin{array}{c}-1.822^{* * *} \\
(0.172)\end{array}$ & $\begin{array}{c}-1.930^{* * *} \\
(0.170)\end{array}$ \\
\hline $\log ($ Selic $)$ & & & $\begin{array}{r}4.305^{*} \\
(2.175) \\
\end{array}$ & $\begin{array}{r}5.094^{*} \\
(2.199) \\
\end{array}$ \\
\hline Time FE & $Y$ & $Y$ & $Y$ & $Y$ \\
\hline Intermediary FE & $N$ & $Y$ & $N$ & $Y$ \\
\hline LR Test & $\begin{array}{c}4,832^{* * *} \\
(\mathrm{df}=30)\end{array}$ & $\begin{array}{c}5,961^{* * *} \\
(\mathrm{df}=48)\end{array}$ & $\begin{array}{c}4,837^{* * *} \\
(\mathrm{df}=31)\end{array}$ & $\begin{array}{c}5,969^{* * *} \\
(\mathrm{df}=49)\end{array}$ \\
\hline
\end{tabular}

Notes: Values reported are the estimated coefficients with robust standard errors in parenthesis. Significance codes as follows: ${ }^{*} \mathrm{p}<0.1 ;{ }^{* *} \mathrm{p}<0.05 ;{ }^{* * *} \mathrm{p}<0.01$

Size dummies throughout this study are in relation to medium enterprises (the reference category). Credit demand estimates indicate that small firms demand smaller loans (i.e. take smaller leverage) than medium and that micro 
demands smaller loans than small firms.

Credit risk rating dummies are in comparison to AA-rating and their effect on demand is different in the specification with and without Intermediaries FE. In the regressions without Intermediaries FE, AA are the most leveraged firms, followed by C, B and A. In the regression with Intermediaries FE, AA are the lest leveraged, followed by A, B and C. There is no ex-ante theoretical prediction ${ }^{1}$ of how risk-assessment should affect demand to evaluate which of the specifications are more accurate ${ }^{2}$.

Grace and amortization length influences positively the loan demand, specially the latter, since ceteris paribus they improved the repayment conditions to the borrower. A $1 \%$ increase in grace and amortization periods leads, respectively, to a 1.2 bps and 24-21 bps increase in the leverage. These results relate to Attanasio, P. K. Goldberg, and Kyriazidou (2008) and Pásztorová (2013) findings of a high elasticity (higher than to interest rate) of low income borrowers to maturity.

On the other hand, the interest rate influences negatively the credit demand, reducing leverage by $2.45-1.55$ bps after a $1 \%$ increase in the interest rate. It is worth noticing that when the log of the Selic rate is included, the elasticities of leverage demand to interest rates slightly increases in module, which could indicate that the implicit subsidy may also be relevant for the demand of BNDES funded loans.

Finally, the dummy indicating Enhancement by definition implicates a positive increase in the leverage of around $15 \%$ and the Total Investment coefficient indicate that larger project are less leveraged (a 1\% larger project leads to a 1.8-1.9 bps decrease in leverage).

Table (A.1) in the Appendix shows the credit demand under the specification without censoring. The relevant contractual conditions remain significant and have a magnitude similar to the Tobit specification.

\section{2}

\section{Default Regressions}

Table (5.2) registers the estimation of the default regression with a Cox proportional hazards specification as in Equation (4-2) with the coefficient associated with Leverage pooling both moral hazard and selection effects.

\footnotetext{
${ }^{1}$ How risk-based priced affects the access of credit for potential borrowers with variable risk is the subject of several empirical studies. Walke, Fullerton, and Tokle (2018) is an example of a recent analysis on this line and provides a brief review on this literature.

${ }^{2}$ For example, if the bank could perfectly foresee a good borrower with its risk assessment, the firm could take the size of loan it wishes.
} 


\section{Table 5.2: Default regression pooling moral hazard and adverse selec-} tion

Table reports Cox proportional hazards regression estimates of Equation (4-2). Leverage is in percentage point. Small and Micro dummies for firm's size are reported with Medium size the reference category. Risk assessment dummies are reported with the best rating, AA-rating, as the reference category. Grace stands for the grace period in months. Amort stands for the amortization period in months. Total Investment is the project's total cost. Specification (2) differs from specification (1) by the inclusion of Brazilian base interest rate, the Selic. All models have month and year fixed effects and each specification is presented with and without intermediary fixed effects

\begin{tabular}{|c|c|c|c|c|}
\hline & \multicolumn{4}{|c|}{$\mathrm{h}($ Perc_paid $): \delta$} \\
\hline & $(1)$ & $(1: \mathrm{FE})$ & $(2)$ & $(2: \mathrm{FE})$ \\
\hline \multirow[t]{2}{*}{ SizeSMALL } & $0.967^{* * *}$ & $0.774^{* * *}$ & $0.953^{* * *}$ & $0.767^{* * *}$ \\
\hline & $(0.127)$ & $(0.128)$ & $(0.127)$ & $(0.128)$ \\
\hline \multirow[t]{2}{*}{ SizeMICRO } & $0.905^{* * *}$ & $0.680^{* * *}$ & $0.907^{* * *}$ & $0.683^{* * *}$ \\
\hline & $(0.118)$ & $(0.123)$ & $(0.118)$ & $(0.123)$ \\
\hline \multirow[t]{2}{*}{ Risk rating $\mathrm{A}$} & $0.578^{* * *}$ & $0.346^{* * *}$ & $0.573^{* * *}$ & $0.345^{* * *}$ \\
\hline & $(0.068)$ & $(0.083)$ & $(0.068)$ & $(0.083)$ \\
\hline \multirow[t]{2}{*}{ Risk rating $B$} & $0.598^{* * *}$ & $0.219^{* * *}$ & $0.591^{* * *}$ & $0.213^{* * *}$ \\
\hline & $(0.063)$ & $(0.079)$ & $(0.063)$ & $(0.079)$ \\
\hline \multirow[t]{2}{*}{ Risk rating $\mathrm{C}$} & $1.021^{* * *}$ & $0.543^{* * *}$ & $1.010^{* * *}$ & $0.537^{* * *}$ \\
\hline & $(0.075)$ & $(0.092)$ & $(0.075)$ & $(0.092)$ \\
\hline \multirow[t]{2}{*}{ Leverage } & $0.027^{* * *}$ & $0.024^{* * *}$ & $0.027^{* * *}$ & $0.024^{* * *}$ \\
\hline & $(0.003)$ & $(0.003)$ & $(0.003)$ & $(0.003)$ \\
\hline \multirow[t]{2}{*}{$\log ($ Grace $)$} & 0.072 & $-0.152^{* * *}$ & 0.080 & $-0.143^{* * *}$ \\
\hline & $(0.059)$ & $(0.051)$ & $(0.059)$ & $(0.053)$ \\
\hline \multirow[t]{2}{*}{$\log$ (Amort) } & $1.497^{* * *}$ & $1.056^{* * *}$ & $1.485^{* * *}$ & $1.049^{* * *}$ \\
\hline & $(0.117)$ & $(0.141)$ & $(0.117)$ & $(0.141)$ \\
\hline \multirow[t]{2}{*}{$\log ($ Interest $)$} & $0.486^{* * *}$ & $0.427^{* * *}$ & $0.738^{* * *}$ & $0.651^{* * *}$ \\
\hline & $(0.094)$ & $(0.092)$ & $(0.121)$ & $(0.120)$ \\
\hline \multirow[t]{2}{*}{$\log ($ Selic $)$} & & & $-1.107^{* * *}$ & $-0.991^{* * *}$ \\
\hline & & & $(0.352)$ & $(0.354)$ \\
\hline \multirow[t]{2}{*}{$\log ($ Total Investment) } & $0.115^{* * *}$ & $0.131^{* * *}$ & $0.113^{* * *}$ & $0.129^{* * *}$ \\
\hline & $(0.026)$ & $(0.027)$ & $(0.026)$ & $(0.027)$ \\
\hline Time FE & $Y$ & $Y$ & $Y$ & $Y$ \\
\hline Intermediary FE & $N$ & $Y$ & $N$ & $Y$ \\
\hline LR Test & $\begin{array}{c}1,027.312^{* * *} \\
(\mathrm{df}=30)\end{array}$ & $\begin{array}{c}1,402.495^{* * *} \\
(\mathrm{df}=48)\end{array}$ & $\begin{array}{c}1,037.021^{* * *} \\
(\mathrm{df}=31)\end{array}$ & $\begin{array}{c}1,410.233^{* * *} \\
(\mathrm{df}=49)\end{array}$ \\
\hline Score Test & $\begin{array}{c}922.894^{* * *} \\
(\mathrm{df}=30)\end{array}$ & $\begin{array}{c}1,425.509^{* * *} \\
(\mathrm{df}=48)\end{array}$ & $\begin{array}{c}928.905^{* * *} \\
(\mathrm{df}=31)\end{array}$ & $\begin{array}{c}1,432.100^{* * *} \\
(\mathrm{df}=49)\end{array}$ \\
\hline
\end{tabular}

Notes: Values reported are the estimated coefficients with robust standard errors in parenthesis. Significance codes as follows: ${ }^{*} \mathrm{p}<0.1 ;{ }^{* *} \mathrm{p}<0.05 ;{ }^{* * *} \mathrm{p}<0.01$

The coefficient associated with the leverage variable indicates that a $1 \%$ increase in leverage leads to a $243-273$ bps increase in the probability of default ${ }^{3}$.

\footnotetext{
${ }^{3}$ The calculation is exactly the hazard ratio: $e x p^{\beta}$
} 
In all specifications the amortization period and the interest rates have positive effects on default. Estimates of the interest rate coefficients indicate that an $1 \%$ increase in the interest rates leads to $48-73$ bps increase in the probability of default.The coefficient related to amortization period indicates that a $1 \%$ increase in this condition leads to a 149-105 bps increase in the probability of default.

The positive effects of interest rates on default were expected from theoretical prediction that riskier borrowers self select into high-leverage highinterest contracts.

On the other hand, the effects of the amortization length are not $a$ priori expected ${ }^{4}$ and whether they reflect moral hazard or selection effects is not derivable from the empirical setting. There are in the literature some studies relating the loan term choice to information problems: Hertzberg, Liberman, and Paravisini (2018) documents in a online lending platform that (ex-post) riskier borrowers self select into long-term high-rate contracts allegedly because long maturity reduces the need to roll over debt at a higher price in the future, which is more probable for high-risk borrowers whose uncertain future observable creditworthiness motivates this choice as an insurance. Pásztorová (2013) also indicates that longer maturity is associated with riskier (liquidity' constrained) borrowers that care more about the value of the instalment (thus accept longer terms to achieve lower installment). We rather avoid any interpretation about our estimates of the effects of the the amortization length on default because this condition was altered less frequently by BNDES, which can affect identification.

The coefficients associated with the size dummies indicates that the smaller the firm is, the riskier it is. Also coefficients of risk assessment categories indicate that worse (ex-ante) credit risk assessment is associated with ex-post riskier loans (Risk A and Risk B are hardly distinguishable), as expected.

Finally, the size of the investment is positively related with default (a 1\% increase in the size of the investment leads to a 11-13 bps increase in default probability), indicating that larger investments are riskier than smaller ones. If we assume that the total investment is a good proxy for the value of the collateral, this result would indicate that the ex-post theory of collateral may be offset by the intrinsic riskiness of larger projects when the project itself is pledged as collateral.

\footnotetext{
${ }^{4}$ We can hypothesize that moral hazard in this context is present because the increase in duration exposes the loan to more shocks that affects the liquidity of the borrower. Selection would come from unobservably different (in risk) borrowers self selecting into loans with different terms in the direction that riskier borrowers chose longer loans
} 
Table (5.3) presents the main finding of this study: accordingly to the interpretation of the empirical model, there are indicatives of advantageous selections and relevant moral hazard in the sample of loans studied.

\section{Table 5.3: Default regression segregating moral hazard and adverse selection}

Table reports Cox proportional hazards regression estimates of Equation (4-2) including the residual $\zeta_{i}$ from first stage credit demand. Leverage is in percentage point. Small and Micro dummies for firm's size are reported with Medium size the reference category. Risk assessment dummies are reported with the best rating, AA-rating, as the reference category. Grace stands for the grace period in months. Amort stands for the amortization period in months. Total Investment is the project's total cost. Specification (2) differs from specification (1) by the inclusion of Brazilian base interest rate, the Selic. All models have month and year fixed effects and each specification is presented with and without intermediary fixed effects

\begin{tabular}{|c|c|c|c|c|}
\hline & \multicolumn{4}{|c|}{$\mathrm{h}($ Perc_paid $): \delta$} \\
\hline & (1) & $(1: \mathrm{FE})$ & $(2)$ & $(2: \mathrm{FE})$ \\
\hline \multirow[t]{2}{*}{ SizeSMALL } & $1.017^{* * *}$ & $0.811^{* * *}$ & $1.002^{* * *}$ & $0.802^{* * *}$ \\
\hline & $(0.127)$ & $(0.129)$ & $(0.127)$ & $(0.129)$ \\
\hline \multirow[t]{2}{*}{ SizeMICRO } & $1.112^{* * *}$ & $0.793^{* * *}$ & $1.109^{* * *}$ & $0.790^{* * *}$ \\
\hline & $(0.128)$ & $(0.129)$ & $(0.128)$ & $(0.129)$ \\
\hline \multirow[t]{2}{*}{ Risk rating $\mathrm{A}$} & $0.657^{* * *}$ & $0.334^{* * *}$ & $0.649^{* * *}$ & $0.333^{* * *}$ \\
\hline & $(0.071)$ & $(0.083)$ & $(0.071)$ & $(0.083)$ \\
\hline \multirow[t]{2}{*}{ Risk rating $B$} & $0.622^{* * *}$ & $0.183^{* *}$ & $0.614^{* * *}$ & $0.179^{* *}$ \\
\hline & $(0.063)$ & $(0.080)$ & $(0.063)$ & $(0.080)$ \\
\hline \multirow[t]{2}{*}{ Risk rating $\mathrm{C}$} & $1.036^{* * *}$ & $0.501^{* * *}$ & $1.024^{* * *}$ & $0.496^{* * *}$ \\
\hline & $(0.075)$ & $(0.093)$ & $(0.075)$ & $(0.093)$ \\
\hline \multirow[t]{2}{*}{ Leverage } & $0.051^{* * *}$ & $0.040^{* * *}$ & $0.051^{* * *}$ & $0.040^{* * *}$ \\
\hline & $(0.006)$ & $(0.006)$ & $(0.006)$ & $(0.006)$ \\
\hline \multirow[t]{2}{*}{$\zeta_{i}$} & $-0.020^{* * *}$ & $-0.014^{* * *}$ & $-0.020^{* * *}$ & $-0.014^{* * *}$ \\
\hline & $(0.005)$ & $(0.005)$ & $(0.005)$ & $(0.005)$ \\
\hline \multirow[t]{2}{*}{$\log ($ Grace $)$} & 0.075 & $-0.150^{* * *}$ & 0.083 & $-0.141^{* * *}$ \\
\hline & $(0.060)$ & $(0.052)$ & $(0.060)$ & $(0.053)$ \\
\hline \multirow[t]{2}{*}{$\log ($ Amort $)$} & $1.099^{* * *}$ & $0.821^{* * *}$ & $1.093^{* * *}$ & $0.826^{* * *}$ \\
\hline & $(0.153)$ & $(0.164)$ & $(0.153)$ & $(0.164)$ \\
\hline \multirow[t]{2}{*}{$\log ($ Interest $)$} & $0.545^{* * *}$ & $0.461^{* * *}$ & $0.807^{* * *}$ & $0.686^{* * *}$ \\
\hline & $(0.095)$ & $(0.093)$ & $(0.123)$ & $(0.121)$ \\
\hline \multirow[t]{2}{*}{$\log ($ Selic $)$} & & & $-1.153^{* * *}$ & $-1.005^{* * *}$ \\
\hline & & & $(0.355)$ & $(0.355)$ \\
\hline $\log ($ Total Investment $)$ & $\begin{array}{l}0.137^{* * *} \\
(0.027)\end{array}$ & $\begin{array}{l}0.146^{* * *} \\
(0.027)\end{array}$ & $\begin{array}{l}0.134^{* * *} \\
(0.027)\end{array}$ & $\begin{array}{l}0.144^{* * *} \\
(0.027)\end{array}$ \\
\hline Time FE & $Y$ & $Y$ & $Y$ & $Y$ \\
\hline Intermediary FE & $N$ & $Y$ & $N$ & $Y$ \\
\hline LR Test & $\begin{array}{c}1,044.858^{* * *} \\
(\mathrm{df}=31)\end{array}$ & $\begin{array}{c}1,410.555^{* * *} \\
(\mathrm{df}=49)\end{array}$ & $\begin{array}{c}1,053.821^{* * *} \\
(\mathrm{df}=32)\end{array}$ & $\begin{array}{c}1,417.483^{* * *} \\
(\mathrm{df}=50)\end{array}$ \\
\hline Score Test & $\begin{array}{c}926.269^{* * *} \\
(\mathrm{df}=31) \\
\end{array}$ & $\begin{array}{c}1,427.017^{* * *} \\
(\mathrm{df}=49)\end{array}$ & $\begin{array}{c}931.998^{* * *} \\
(\mathrm{df}=32)\end{array}$ & $\begin{array}{c}1,433.401^{* * *} \\
(\mathrm{df}=50)\end{array}$ \\
\hline
\end{tabular}

Notes: Values reported are the estimated coefficients with robust standard errors in parenthesis. Significance codes as follows: ${ }^{*} \mathrm{p}<0.1 ;{ }^{* *} \mathrm{p}<0.05 ;{ }^{* * *} \mathrm{p}<0.01$ 
The coefficient associated with the leverage variable indicates that moral hazard makes a $1 \%$ increase in leverage leads to a $408-523$ bps increase in the probability of default. Advantageous selection works to mitigate almost half of the moral hazard effects decreasing the probability to default in 159-227 bps after a $1 \%$ increase in leverage due to unobservable reason. The other regressors keep the same interpretation and similar magnitudes of effects as the ones in Table (5.2).

Notice that advantageous selection should be interpreted as the following: the information not captured by the variables observed by the econometrician (in our case the same as FGI/BNDES) that works in the direction of increasing the leverage also decreases ex-post default. Hence, it must be pointed that the result of advantageous selection could be related to data missing to the econometrician/FGI/BNDES but maybe not to intermediary banks, such as soft information or intra-groups variation, that correlates negatively with default and positively with the leverage.

Since loans are originated by intermediary banks, BNDES and FGI lack soft and quantitative data on borrowers (besides the ones compiled in the risk assessment) that may be accessible to intermediary banks. Accordingly, our result of (advantageous) selection, using the information set available for the BNDES and the FGI, must be restricted to their perspective, i.e., we are assessing asymmetric information between the BNDES or the FGI and the final borrower and there is no guarantee that this result would persist if we conduct the same analysis using intermediary banks proprietary information.

With that caveat in mind, in the next section we perform several robustness tests to confirm that the result sustains under different specifications. We will defer the exposition of conjectures on the possible causes of this result of advantageous selection to Section 7 when we explore the enhancement option to gain further insight on this issue.

\subsection{1}

\section{Risk Assessment Analysis}

Lastly, Table (5.4) presents the results of the regression when risk assessment is omitted. Corroborating visual evidences from Figure (3.1(a)), risk rating seems to have negligible effect on mitigating asymmetric information: the coefficient linking leverage to default stays the same or slightly decreases in relation to the ones reported in Table (5.2). 
Table 5.4: Default regression omitting risk-assessment

Table reports Cox proportional hazards regression estimates of Equation (4-2) omitting risk assessment dummies. Leverage is in percentage point. Small and Micro dummies for firm's size are reported with Medium size the reference category. Grace stands for the grace period in months. Amort stands for the amortization period in months. Total Investment is the project's total cost. Specification (2) differs from specification (1) by the inclusion of Brazilian base interest rate, the Selic. All models have month and year fixed effects and each specification is presented with and without intermediary fixed effects

\begin{tabular}{|c|c|c|c|c|}
\hline & \multicolumn{4}{|c|}{$\mathrm{h}($ Perc_paid $): \delta$} \\
\hline & $(1)$ & $(1: \mathrm{FE})$ & $(2)$ & $(2: \mathrm{FE})$ \\
\hline \multirow[t]{2}{*}{ SizeSMALL } & $0.883^{* * *}$ & $0.743^{* * *}$ & $0.869^{* * *}$ & $0.737^{* * *}$ \\
\hline & $(0.126)$ & $(0.129)$ & $(0.126)$ & $(0.128)$ \\
\hline \multirow{2}{*}{ SizeMICRO } & $0.757^{* * *}$ & $0.664^{* * *}$ & $0.761^{* * *}$ & $0.667^{* * *}$ \\
\hline & $(0.117)$ & $(0.123)$ & $(0.117)$ & $(0.123)$ \\
\hline \multirow[t]{2}{*}{ Leverage } & $0.023^{* * *}$ & $0.024^{* * *}$ & $0.024^{* * *}$ & $0.024^{* * *}$ \\
\hline & $(0.002)$ & $(0.003)$ & $(0.002)$ & $(0.003)$ \\
\hline \multirow[t]{2}{*}{$\log ($ Grace $)$} & 0.011 & $-0.173^{* * *}$ & 0.019 & $-0.165^{* * *}$ \\
\hline & $(0.057)$ & $(0.048)$ & $(0.058)$ & $(0.049)$ \\
\hline \multirow[t]{2}{*}{$\log ($ Amort $)$} & $1.132^{* * *}$ & $1.136^{* * *}$ & $1.120^{* * *}$ & $1.129^{* * *}$ \\
\hline & $(0.108)$ & $(0.142)$ & $(0.108)$ & $(0.142)$ \\
\hline \multirow[t]{2}{*}{$\log ($ Interest $)$} & $0.568^{* * *}$ & $0.475^{* * *}$ & $0.880^{* * *}$ & $0.703^{* * *}$ \\
\hline & $(0.094)$ & $(0.092)$ & $(0.120)$ & $(0.119)$ \\
\hline $\log ($ Selic $)$ & & & $-1.372^{* * *}$ & $-1.018^{* * *}$ \\
\hline $\log ($ Total Investment) & $\begin{array}{l}0.131^{* * *} \\
(0.027)\end{array}$ & $\begin{array}{l}0.127^{\text {*** }} \\
(0.027) \\
\end{array}$ & $\begin{array}{c}(0.352) \\
0.128^{* * *} \\
(0.027)\end{array}$ & $\begin{array}{c}(0.353) \\
0.125^{* * *} \\
(0.027) \\
\end{array}$ \\
\hline Time FE & $Y$ & $Y$ & $Y$ & $Y$ \\
\hline Intermediary FE & $N$ & $Y$ & $N$ & $Y$ \\
\hline LR Test & $\begin{array}{c}831.794^{* * *} \\
(\mathrm{df}=27)\end{array}$ & $\begin{array}{c}1,360.314^{* * *} \\
(\mathrm{df}=45)\end{array}$ & $\begin{array}{c}846.711^{* * *} \\
(\mathrm{df}=28)\end{array}$ & $\begin{array}{c}1,368.523^{* * *} \\
(\mathrm{df}=46)\end{array}$ \\
\hline Score Test & $\begin{array}{c}792.841^{* * *} \\
(\mathrm{df}=27)\end{array}$ & $\begin{array}{c}1,377.404^{* * *} \\
(\mathrm{df}=45)\end{array}$ & $\begin{array}{c}803.493^{* * *} \\
(\mathrm{df}=28)\end{array}$ & $\begin{array}{c}1,385.056^{* * *} \\
(\mathrm{df}=46)\end{array}$ \\
\hline
\end{tabular}

Notes: Values reported are the estimated coefficients with robust standard errors in parenthesis. Significance codes as follows: ${ }^{*} \mathrm{p}<0.1 ;{ }^{* *} \mathrm{p}<0.05 ;{ }^{* * *} \mathrm{p}<0.01$

It is worth noting that the only variable whose coefficients shows monotone changes is the interest rate - all coefficients in Table (5.4) are higher than the ones in Table (5.2). This may suggest that risk assessment is used by banks to price discriminate in risk-based pricing (i.e., that the risk assessment allows banks to charge higher rates up to the limit that the borrower repay without defaulting), instead of being used to restrict the size of the loans demanded. 
6

\section{Robustness Test}

We tested the robustness of the previous results in three ways: first, under different specifications for the default regression, next, by exploring a sub-sample around changes in policies looking for sharper identification, and lastly, by restricting the definition of default.

\section{1}

\section{Others Specifications for Default Regression}

Table (6.1) presents the estimations of the default model under a linear probability model (LPM), Probit and Logit specification ${ }^{1}$.

${ }^{1}$ Due to dimensionality concerns in the Probit and Logit, the regressions do not include Intermediary fixed effects. 


\section{Table 6.1: Default regression with alternative specifications}

Table reports alternative specifications for the default regression. Dependent variable is I_Default which equals 1 if the loan defaulted and 0 otherwise. Leverage is in percentage point. Small and Micro dummies for firm's size are reported with Medium size the reference category. Risk assessment dummies are reported with the best rating, AArating, as the reference category. Grace stands for the grace period in months. Amort stands for the amortization period in months. Total Investment is the project's total cost. Specification (2) differs from specification (1) by the inclusion of Brazilian base interest rate, the Selic. All models have month and year fixed effects and LPM model includes intermediary fixed effects.

\begin{tabular}{|c|c|c|c|c|c|c|}
\hline & \multicolumn{6}{|c|}{ I_Default } \\
\hline & \multicolumn{2}{|c|}{ Linear Probability Model } & \multicolumn{2}{|c|}{ Probit } & \multicolumn{2}{|c|}{ Logit } \\
\hline & $(\mathrm{MH}+\mathrm{AS})$ & $($ MHvsAS) & $(\mathrm{MH}+\mathrm{AS})$ & $(\mathrm{MHxAS})$ & $(\mathrm{MH}+\mathrm{AS})$ & $(\mathrm{MHxAS})$ \\
\hline (Constant) & $\begin{array}{c}-0.982^{* * *} \\
(0.055)\end{array}$ & $\begin{array}{c}-1.025^{* * *} \\
(0.057)\end{array}$ & $\begin{array}{c}-7.045^{* * *} \\
(0.300)\end{array}$ & $\begin{array}{c}-7.477^{* * *} \\
(0.319)\end{array}$ & $\begin{array}{c}-13.243^{* * *} \\
(0.570)\end{array}$ & $\begin{array}{c}-14.156^{* * *} \\
(0.611)\end{array}$ \\
\hline SizeSMALL & $\begin{array}{c}0.079^{* * *} \\
(0.012)\end{array}$ & $\begin{array}{l}0.082^{* * *} \\
(0.012)\end{array}$ & $\begin{array}{l}0.513^{* * *} \\
(0.070)\end{array}$ & $\begin{array}{c}0.545^{* * *} \\
(0.070)\end{array}$ & $\begin{array}{l}1.013^{* * *} \\
(0.136)\end{array}$ & $\begin{array}{l}1.071^{* * *} \\
(0.137)\end{array}$ \\
\hline SizeMICRO & $\begin{array}{l}0.077^{\text {*** }} \\
(0.011)\end{array}$ & $\begin{array}{l}0.092^{* * *} \\
(0.012)\end{array}$ & $\begin{array}{l}0.489^{* * *} \\
(0.063)\end{array}$ & $\begin{array}{l}0.613^{\text {*** }} \\
(0.070)\end{array}$ & $\begin{array}{l}0.959^{* * *} \\
(0.126)\end{array}$ & $\begin{array}{l}1.198^{* * *} \\
(0.138)\end{array}$ \\
\hline Risk rating $\mathrm{A}$ & $\begin{array}{l}0.053^{* * *} \\
(0.008)\end{array}$ & $\begin{array}{l}0.058^{* * *} \\
(0.008)\end{array}$ & $\begin{array}{l}0.247^{* * *} \\
(0.041)\end{array}$ & $\begin{array}{l}0.295^{\text {*** }} \\
(0.042)\end{array}$ & $\begin{array}{l}0.510^{* * *} \\
(0.075)\end{array}$ & $\begin{array}{l}0.604^{* * *} \\
(0.078)\end{array}$ \\
\hline Risk rating $B$ & $\begin{array}{l}0.060^{* * *} \\
(0.008)\end{array}$ & $\begin{array}{l}0.063^{* * *} \\
(0.008)\end{array}$ & $\begin{array}{l}0.339^{* * *} \\
(0.038)\end{array}$ & $\begin{array}{c}0.357^{* * *} \\
(0.038)\end{array}$ & $\begin{array}{l}0.639^{* * *} \\
(0.070)\end{array}$ & $\begin{array}{l}0.672^{\text {*** }} \\
(0.070)\end{array}$ \\
\hline Risk rating $\mathrm{C}$ & $\begin{array}{l}0.103^{* * *} \\
(0.009)\end{array}$ & $\begin{array}{l}0.104^{* * *} \\
(0.009)\end{array}$ & $\begin{array}{l}0.563^{* * *} \\
(0.045)\end{array}$ & $\begin{array}{l}0.574^{* * *} \\
(0.045)\end{array}$ & $\begin{array}{l}1.078^{* * *} \\
(0.083)\end{array}$ & $\begin{array}{l}1.098^{* * *} \\
(0.083)\end{array}$ \\
\hline Leverage & $\begin{array}{c}0.003^{* * *} \\
(0.0003)\end{array}$ & $\begin{array}{c}0.004^{* * *} \\
(0.001)\end{array}$ & $\begin{array}{l}0.015^{* * *} \\
(0.001)\end{array}$ & $\begin{array}{c}0.028^{* * *} \\
(0.004)\end{array}$ & $\begin{array}{l}0.028^{* * *} \\
(0.003)\end{array}$ & $\begin{array}{c}0.056^{* * *} \\
(0.007)\end{array}$ \\
\hline$\zeta_{i}$ & & $\begin{array}{c}-0.001^{* * *} \\
(0.001)\end{array}$ & & $\begin{array}{c}-0.012^{* * *} \\
(0.003)\end{array}$ & & $\begin{array}{c}-0.023^{* * *} \\
(0.005)\end{array}$ \\
\hline $\log ($ Grace $)$ & $\begin{array}{c}0.005 \\
(0.006)\end{array}$ & $\begin{array}{c}0.005 \\
(0.006)\end{array}$ & $\begin{array}{c}0.019 \\
(0.034)\end{array}$ & $\begin{array}{c}0.022 \\
(0.034)\end{array}$ & $\begin{array}{c}0.0004 \\
(0.063)\end{array}$ & $\begin{array}{c}0.003 \\
(0.064)\end{array}$ \\
\hline $\log ($ Amort $)$ & $\begin{array}{l}0.136^{* * *} \\
(0.012)\end{array}$ & $\begin{array}{l}0.109^{* * *} \\
(0.016)\end{array}$ & $\begin{array}{l}0.672^{* * *} \\
(0.066)\end{array}$ & $\begin{array}{l}0.443^{* * *} \\
(0.086)\end{array}$ & $\begin{array}{l}1.302^{* * *} \\
(0.125)\end{array}$ & $\begin{array}{c}0.845^{* * *} \\
(0.164)\end{array}$ \\
\hline $\log ($ Interest $)$ & $\begin{array}{l}0.053^{* * *} \\
(0.012)\end{array}$ & $\begin{array}{l}0.056^{* * *} \\
(0.012)\end{array}$ & $\begin{array}{l}0.262^{* * *} \\
(0.056)\end{array}$ & $\begin{array}{l}0.291^{\text {*** }} \\
(0.057)\end{array}$ & $\begin{array}{l}0.482^{\text {*** }} \\
(0.103)\end{array}$ & $\begin{array}{l}0.547^{* * *} \\
(0.105)\end{array}$ \\
\hline $\log ($ Tot. Invest.) & $\begin{array}{l}0.011^{* * *} \\
(0.003)\end{array}$ & $\begin{array}{l}0.013^{* * *} \\
(0.003)\end{array}$ & $\begin{array}{l}0.065^{* * *} \\
(0.016)\end{array}$ & $\begin{array}{l}0.075^{* * *} \\
(0.016)\end{array}$ & $\begin{array}{l}0.121^{* * *} \\
(0.029)\end{array}$ & $\begin{array}{l}0.144^{* * *} \\
(0.030)\end{array}$ \\
\hline
\end{tabular}

Notes: Values reported are the estimated coefficients with robust standard errors in parenthesis. Significance codes as follows: ${ }^{*} \mathrm{p}<0.1{ }^{* *} \mathrm{p}<0.05 ;{ }^{* * *} \mathrm{p}<0.01$

Notice that, for all three alternative specifications, we have the same interpretation of moral hazard as a relevant phenomenon partially offset by advantageous selection. 
LPM marginal effects indicate that a $1 \%$ increase in leverage leads to a 0.4 bps moral hazard increase in default which is reduced in 0.1 bps by advantageous selection. Accordingly, Probit mean marginal effects of moral hazard is 0.006 and of advantageous selection is -0.002. Lastly, Logit mean marginal effects are 0.006 and -0.003 .

\section{2}

\section{Chiaporie Salanie Test}

The result of the pooled effect of asymmetric information on the choice of leverage can be assessed using Chiappori and Salanie (2000) traditional test. To do so we run the default regression using a LPM, Probit and Logit modelling, but excluding from these equations all terms of the contract under choice (i.e. the menu of interest rate and leverage). The (generalized) residual from these regressions is then inserted in the leverage demand ${ }^{2}$, where a positive correlation indicate the presence of asymmetric information in leverage choice, i.e., those who chose higher leverage defaulted more ex-post. Table (6.2) presents the results from this coefficients and their significance.

\section{Table 6.2: Chiappori and Salanie (2000) test of asymmetric informa- tion}

Table reports the coefficient in the credit demand regression associated with the residual of the default regression specified with a LPM,Probit and Tobit.

\begin{tabular}{lcc}
\hline Default Model: & $\begin{array}{c}\text { Coefficient of } \\
\text { Default Residual }\end{array}$ & Robust SD \\
\hline LPM & $3.09^{* * *}$ & 0.329 \\
Probit & $1.17^{* * *}$ & 0.13 \\
Tobit & $1.15^{* * *}$ & 0.13 \\
\hline
\end{tabular}

Notes: Significance codes as follows: ${ }^{*} \mathrm{p}<0.1 ;{ }^{* *} \mathrm{p}<0.05$; ${ }^{* * *} \mathrm{p}<0.01$

The significance and signal of the coefficients of the default residual in all specifications corroborate the finding shown in Table (5.2) that the pool of moral hazard and selection in the choice of leverage is relevant and affects negatively the banks.

${ }^{2}$ Also including the predicted probability of making late payments as suggested by Edelberg (2004). 


\section{3}

\section{Event Study}

Table (6.3) shows the results for the default model (demand was also estimated) estimated considering only a window of 3 months after and before the reforms indicated in Table $(2.1)^{3}$. The logic behind this robustness test is to explore a subsample of loans originated around changes in the credit conditions when we can have isolated exogenous variation in the credit conditions and supposedly a sharper identification.

Results in Table (6.3) are similar to the ones in Table (5.3) and the interpretation of advantageous selection and moral hazard remains.

${ }^{3}$ The month where the reform took place is excluded because what matters to determine the condition is the date of the solicitation and not when it was contracted 
Table 6.3: Default regression in reform bordering subsample

Table reports Cox proportional hazards regression estimates of Equation (4-2) on the subsample of loans originated in the window of 3 months before and after BNDES credit reforms. Models are present with and without Intermediary fixed effects and with and without the residual $\zeta_{i}$ from first stage credit demand. Leverage is in percentage point. Small and Micro dummies for firm's size are reported with Medium size the reference category. Risk assessment dummies are reported with the best rating, AArating, as the reference category. Grace stands for the grace period in months. Amort stands for the amortization period in months. Total Investment is the project's total cost. Specification (2) differs from specification (1) by the inclusion of Brazilian base interest rate, the Selic. All models have month and year fixed effects.

\begin{tabular}{|c|c|c|c|c|}
\hline & \multicolumn{4}{|c|}{$\mathrm{h}($ Perc_paid $): \delta$} \\
\hline & \multicolumn{2}{|c|}{1} & \multicolumn{2}{|c|}{ 1:FE } \\
\hline & $(\mathrm{MH}+\mathrm{AS})$ & $(\mathrm{MHxAS})$ & $(\mathrm{MH}+\mathrm{AS})$ & $(\mathrm{MHxAS})$ \\
\hline SizeSMALL & $\begin{array}{c}0.635^{* *} \\
(0.249)\end{array}$ & $\begin{array}{c}0.721^{* * *} \\
(0.255)\end{array}$ & $\begin{array}{c}0.391 \\
(0.259)\end{array}$ & $\begin{array}{l}0.663^{\text {*** }} \\
(0.254)\end{array}$ \\
\hline SizeMICRO & $\begin{array}{c}0.509^{* *} \\
(0.239)\end{array}$ & $\begin{array}{c}0.693^{* * *} \\
(0.268)\end{array}$ & $\begin{array}{c}0.210 \\
(0.252)\end{array}$ & $\begin{array}{c}0.570^{* *} \\
(0.263)\end{array}$ \\
\hline Risk rating $\mathrm{A}$ & $\begin{array}{l}0.520^{* * *} \\
(0.190)\end{array}$ & $\begin{array}{l}0.528^{* * *} \\
(0.190)\end{array}$ & $\begin{array}{c}0.508^{* *} \\
(0.233)\end{array}$ & $\begin{array}{l}0.526^{* * *} \\
(0.191)\end{array}$ \\
\hline Risk rating $\mathrm{B}$ & $\begin{array}{c}0.356^{*} \\
(0.186)\end{array}$ & $\begin{array}{c}0.304 \\
(0.188)\end{array}$ & $\begin{array}{c}0.157 \\
(0.217)\end{array}$ & $\begin{array}{r}0.348^{*} \\
(0.187)\end{array}$ \\
\hline Risk rating $\mathrm{C}$ & $\begin{array}{c}0.422^{*} \\
(0.237)\end{array}$ & $\begin{array}{c}0.397^{*} \\
(0.237)\end{array}$ & $\begin{array}{c}0.239 \\
(0.272)\end{array}$ & $\begin{array}{c}0.419^{*} \\
(0.237)\end{array}$ \\
\hline Leverage & $\begin{array}{l}0.018^{* * *} \\
(0.007)\end{array}$ & $\begin{array}{c}0.036^{* * *} \\
(0.014)\end{array}$ & $\begin{array}{l}0.019^{* * *} \\
(0.007)\end{array}$ & $\begin{array}{c}0.023^{*} \\
(0.012)\end{array}$ \\
\hline$\zeta_{i}$ & & $\begin{array}{r}-0.017 \\
(0.011)\end{array}$ & & $\begin{array}{r}-0.006 \\
(0.010)\end{array}$ \\
\hline $\log ($ Grace $)$ & $\begin{array}{c}-0.072 \\
(0.101)\end{array}$ & $\begin{array}{c}-0.069 \\
(0.106)\end{array}$ & $\begin{array}{r}-0.154^{*} \\
(0.085)\end{array}$ & $\begin{array}{c}-0.071 \\
(0.102)\end{array}$ \\
\hline $\log$ (Amort) & $\begin{array}{l}1.546^{* * *} \\
(0.297)\end{array}$ & $\begin{array}{l}1.295^{\text {*** }} \\
(0.342)\end{array}$ & $\begin{array}{c}0.941^{* *} \\
(0.377)\end{array}$ & $\begin{array}{l}1.464^{* * *} \\
(0.331)\end{array}$ \\
\hline $\log ($ Interest $)$ & $\begin{array}{l}1.586^{* * *} \\
(0.506)\end{array}$ & $\begin{array}{l}1.480^{* * *} \\
(0.527)\end{array}$ & $\begin{array}{c}1.138^{* *} \\
(0.493)\end{array}$ & $\begin{array}{l}1.544^{\text {*** }} \\
(0.515)\end{array}$ \\
\hline $\log ($ Total Investment) & $\begin{array}{c}0.321^{* * *} \\
(0.077)\end{array}$ & $\begin{array}{c}0.328^{* * *} \\
(0.078)\end{array}$ & $\begin{array}{c}0.300^{* * *} \\
(0.077)\end{array}$ & $\begin{array}{c}0.324^{* * *} \\
(0.077)\end{array}$ \\
\hline Observations & 2,075 & 2,075 & 2,075 & 2,075 \\
\hline LR Test & $\begin{array}{c}191.884^{* * *} \\
(\mathrm{df}=21)\end{array}$ & $\begin{array}{c}194.221^{* * *} \\
(\mathrm{df}=22)\end{array}$ & $\begin{array}{c}273.621^{* * *} \\
(\mathrm{df}=36)\end{array}$ & $\begin{array}{c}192.197^{* * *} \\
(\mathrm{df}=22)\end{array}$ \\
\hline Score Test & $\begin{array}{c}161.172^{* * *} \\
(\mathrm{df}=21)\end{array}$ & $\begin{array}{c}161.569^{* * *} \\
(\mathrm{df}=22)\end{array}$ & $\begin{array}{c}243.555^{* * *} \\
(\mathrm{df}=36)\end{array}$ & $\begin{array}{c}161.173^{* * *} \\
(\mathrm{df}=22)\end{array}$ \\
\hline
\end{tabular}

Notes: Values reported are the estimated coefficients with robust standard errors in parenthesis. Significance codes as follows: ${ }^{*} \mathrm{p}<0.1 ;{ }^{* *} \mathrm{p}<0.05 ;{ }^{* * *} \mathrm{p}<0.01$ 


\section{4}

\section{Alternative default specification}

Finally, to show that the main results are not driven by our definition of default, next we will present the results assuming a default only when the loan is accelerated (i.e., the FGI is executed). Under this definition $8.2 \%$ of the loans in the sample defaulted during the period.

First, Figures (6.1(b)) and (6.1(a)) display the histogram of payments until this alternative definition of default:

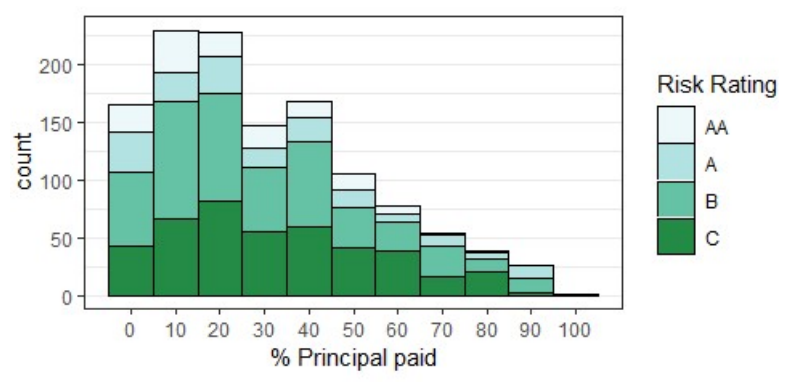

(6.1(a)) by risk type

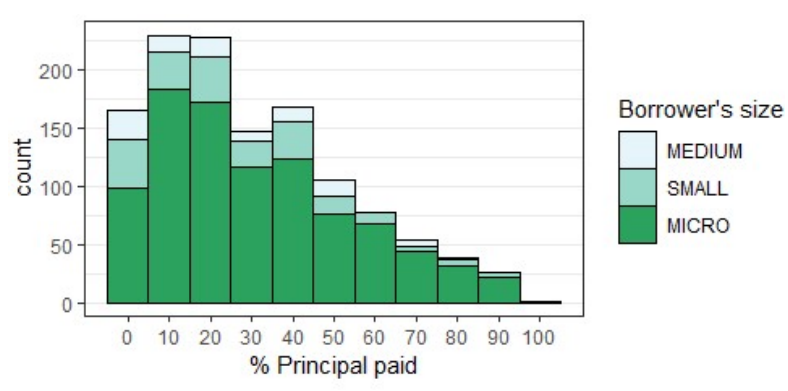

(6.1(b)) by borrower's size

Figure 6.1: Histograms of \% Payed before Loan Acceleration

Notice that unlike in Figure (3.1(a)), risk-assessment seems to predict better this definition of default.

Table (6.4) reproduces the estimates of the (1) and (1:FE) specifications in Tables (5.2)-(5.4), sustaining the interpretation of moral hazard and advantageous selection. 


\section{Table 6.4: Default regression with alternative default definition}

Table reports Cox proportional hazard regression estimates of Equation (4-2) with default defined as only the event when the loan is accelerated. Models are present with and without Intermediary fixed effects, with and without the residual $\zeta_{i}$ from first stage credit demand, and with and without risk assessment. Leverage is in percentage point. Small and Micro dummies for firm's size are reported with Medium size the reference category. Risk assessment dummies are reported with the best rating, AA-rating, as the reference category. Grace stands for the grace period in months. Amort stands for the amortization period in months. Total Investment is the project's total cost. Specification (2) differs from specification (1) by the inclusion of Brazilian base interest rate, the Selic. All models have month and year fixed effects.

\begin{tabular}{|c|c|c|c|c|c|c|}
\hline \multirow[b]{2}{*}{ SizeSMALL } & \multicolumn{6}{|c|}{$\mathrm{h}($ Perc_paid $): \delta$} \\
\hline & $\begin{array}{c}0.518^{* * *} \\
(0.125)\end{array}$ & $\begin{array}{l}0.438^{* * *} \\
(0.127)\end{array}$ & $\begin{array}{l}0.575^{* * *} \\
(0.126)\end{array}$ & $\begin{array}{l}0.478^{* * *} \\
(0.128)\end{array}$ & $\begin{array}{c}0.548^{* * *} \\
(0.124)\end{array}$ & $\begin{array}{c}0.434^{* * *} \\
(0.127)\end{array}$ \\
\hline SizeMICRO & $\begin{array}{c}0.116 \\
(0.117)\end{array}$ & $\begin{array}{c}0.090 \\
(0.124)\end{array}$ & $\begin{array}{l}0.351^{* * *} \\
(0.132)\end{array}$ & $\begin{array}{c}0.211 \\
(0.133)\end{array}$ & $\begin{array}{c}0.034 \\
(0.117)\end{array}$ & $\begin{array}{c}0.047 \\
(0.124)\end{array}$ \\
\hline Risk rating A & $\begin{array}{l}0.474^{* * *} \\
(0.117)\end{array}$ & $\begin{array}{c}-0.028 \\
(0.132)\end{array}$ & $\begin{array}{l}0.554^{* * *} \\
(0.119)\end{array}$ & $\begin{array}{r}-0.037 \\
(0.132)\end{array}$ & & \\
\hline Risk rating $B$ & $\begin{array}{l}1.212^{* * *} \\
(0.099)\end{array}$ & $\begin{array}{c}0.303^{* * *} \\
(0.113)\end{array}$ & $\begin{array}{l}1.248^{* * *} \\
(0.100)\end{array}$ & $\begin{array}{c}0.271^{* *} \\
(0.114)\end{array}$ & & \\
\hline Risk rating $\mathrm{C}$ & $\begin{array}{l}1.632^{* * *} \\
(0.105)\end{array}$ & $\begin{array}{l}0.667^{* * *} \\
(0.122)\end{array}$ & $\begin{array}{l}1.639^{* * *} \\
(0.105)\end{array}$ & $\begin{array}{c}0.622^{* * *} \\
(0.123)\end{array}$ & & \\
\hline Leverage & $\begin{array}{l}0.018^{* * *} \\
(0.003)\end{array}$ & $\begin{array}{l}0.021^{\text {*** }} \\
(0.003)\end{array}$ & $\begin{array}{l}0.042^{* * *} \\
(0.007)\end{array}$ & $\begin{array}{c}0.038^{* * *} \\
(0.007)\end{array}$ & $\begin{array}{l}0.016^{* * *} \\
(0.003)\end{array}$ & $\begin{array}{l}0.022^{\text {*** }} \\
(0.003)\end{array}$ \\
\hline$\zeta_{i}$ & & & $\begin{array}{c}-0.022^{* * *} \\
(0.006)\end{array}$ & $\begin{array}{c}-0.015^{* *} \\
(0.006)\end{array}$ & & \\
\hline $\log ($ Grace $)$ & $\begin{array}{c}0.002 \\
(0.064)\end{array}$ & $\begin{array}{c}0.234^{*} \\
(0.121)\end{array}$ & $\begin{array}{c}0.010 \\
(0.068)\end{array}$ & $\begin{array}{c}0.247^{* *} \\
(0.121)\end{array}$ & $\begin{array}{c}-0.126^{* * *} \\
(0.046)\end{array}$ & $\begin{array}{c}0.185 \\
(0.118)\end{array}$ \\
\hline $\log ($ Amort $)$ & $\begin{array}{r}-0.013 \\
(0.136)\end{array}$ & $\begin{array}{c}0.482^{* *} \\
(0.199)\end{array}$ & $\begin{array}{c}-0.458^{* *} \\
(0.182)\end{array}$ & $\begin{array}{c}0.215 \\
(0.229)\end{array}$ & $\begin{array}{c}-0.245^{* *} \\
(0.119)\end{array}$ & $\begin{array}{c}0.576^{* * *} \\
(0.200)\end{array}$ \\
\hline $\log ($ Interest $)$ & $\begin{array}{c}0.063 \\
(0.112)\end{array}$ & $\begin{array}{c}-0.043 \\
(0.113)\end{array}$ & $\begin{array}{c}0.115 \\
(0.114)\end{array}$ & $\begin{array}{r}-0.009 \\
(0.114)\end{array}$ & $\begin{array}{c}0.275^{* *} \\
(0.112)\end{array}$ & $\begin{array}{c}0.039 \\
(0.113)\end{array}$ \\
\hline $\log$ (Tot. Invest.) & $\begin{array}{c}0.047 \\
(0.034)\end{array}$ & $\begin{array}{c}0.025 \\
(0.034) \\
\end{array}$ & $\begin{array}{r}0.066^{*} \\
(0.034) \\
\end{array}$ & $\begin{array}{c}0.039 \\
(0.035) \\
\end{array}$ & $\begin{array}{c}0.083^{* *} \\
(0.034) \\
\end{array}$ & $\begin{array}{c}0.017 \\
(0.034) \\
\end{array}$ \\
\hline Time FE & $Y$ & $Y$ & $Y$ & $Y$ & $Y$ & $Y$ \\
\hline Intermediary FE & $N$ & Y & $N$ & Y & $N$ & $Y$ \\
\hline LR Test & $\begin{array}{c}532.424^{* * *} \\
(\mathrm{df}=30)\end{array}$ & $\begin{array}{c}861.883^{* * *} \\
(\mathrm{df}=47)\end{array}$ & $\begin{array}{c}547.161^{* * *} \\
(\mathrm{df}=31)\end{array}$ & $\begin{array}{c}867.811^{* * *} \\
(\mathrm{df}=48)\end{array}$ & $\begin{array}{c}176.641^{* * *} \\
(\mathrm{df}=27)\end{array}$ & $\begin{array}{c}806.630^{* * *} \\
(\mathrm{df}=44)\end{array}$ \\
\hline Score Test & $\begin{array}{l}542.518^{* * *} \\
(\mathrm{df}=30)\end{array}$ & $\begin{array}{l}709.165^{* * *} \\
(\mathrm{df}=47)\end{array}$ & $\begin{array}{l}561.687^{* * *} \\
(\mathrm{df}=31)\end{array}$ & $\begin{array}{l}717.322^{* * *} \\
(\mathrm{df}=48)\end{array}$ & $\begin{array}{l}186.381^{* * *} \\
(\mathrm{df}=27)\end{array}$ & $\begin{array}{l}631.527^{* * *} \\
(\mathrm{df}=44)\end{array}$ \\
\hline
\end{tabular}

Notes: Values reported are the estimated coefficients with robust standard errors in parenthesis. Significance codes as follows: ${ }^{*} \mathrm{p}<0.1 ;{ }^{* *} \mathrm{p}<0.05 ;{ }^{* * *} \mathrm{p}<0.01$ 
It can be noticed that under the alternative specification of default, amortization and interest rates are no longer significant predictors. When rating is omitted from the regression, these variables show significance under some of the specifications, but overall only risk assessment, leverage and size are relevant predictors of ex-post default under this alternative definition.

Observe that risk categories estimates corroborate the graphical evidence from Figures (6.1(b)) and (6.1(a)), increasingly capturing ex-post default pattern, under this restrictive definition of default. The analysis of the effects of risk assessment on leverage, once again points out that banks do no seem to use it to restrict leverage, but to extract surplus by charging higher interest rates ${ }^{4}$.

Lastly, from the FGI Annual Result Reports we can observe that the values recovered represents around $30 \%$ of the claims honored ${ }^{5}$. We can use this proxy of overall recovery when the loan is accelerated to assess, in a simplistic exercise, the effects of default (under the definition in this section ${ }^{6}$ ) on spreads. We use the estimates of the hazard equation in the first column under the $(\mathrm{MH}+\mathrm{AS})$ in Table (6.4), assuming a recovery rate of $30 \%$ after default and calculate what is the spread necessary to compensate for defaults if the lender wants to receive a $6.13 \% / \mathrm{yr}$ riskless interest rate (this is the average interest rate) ${ }^{7}$. Taking an average loan from the sample ${ }^{8}$, we estimate that $2.46 \mathrm{pp}$ spread (i.e. an $40.16 \%$ increase in the riskless interest rate) is necessary to compensate banks for default pattern. After a increase $1 \mathrm{pp}$ increase in the base leverage, which could be due to the aggregate result of moral hazard and selection, the spread increase to $2.51 \mathrm{pp}$, i.e. asymmetric information leading to a $1 \mathrm{pp}$ increase in leverage could lead to a $5 \mathrm{bps}$ increase in the spread, or equivalently a $2 \%$ increase in the spread.

Figure 6.2 plots the spread to compensate for default by the leverage chosen by the borrower.

\footnotetext{
${ }^{4}$ Notice the same interpretation as before when comparing the coefficient of the interest rate under the $(\mathrm{MH}+\mathrm{AS})$ headline and under the (Rating) headline.

${ }^{5}$ From 2015 to 2018 FGI honored $\mathrm{R} \$ 145.9$ millions and recovered $\mathrm{R} \$ 42.9$ millions.

${ }^{6}$ We do not have data, micro or aggregate, on renegotiation outputs so we cannot replicate this calculation.

${ }^{7}$ We use the equivalent compound rate for calculations with the richer grid of time cut-offs and hazard rates generated in the estimation

${ }^{8} \mathrm{~A}$ loan contracted by a micro firm in nov/2013 with leverage of 83.06 , size of 249.79 , grace Period of 5 months, amortization period of 68 months and with a risk assessment of B.
} 


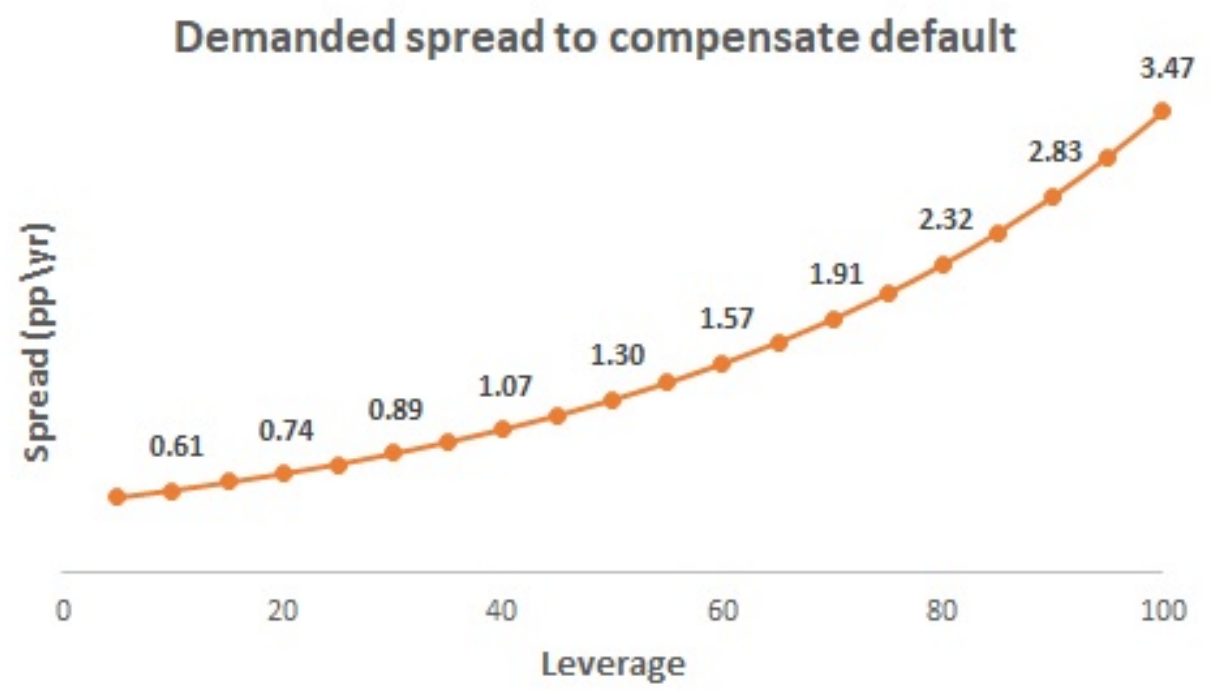

Figure 6.2: Spread demanded to overcome default pattern of an average loan in the sample

Notice that asymmetric information in the choice of leverage should motivate a pricing schedule that is increasing in the leverage, and this relation is more than proportional. If there was no asymmetric information embedded in the choice of leverage by the borrower, this simplistic exercise would indicate that a uniform spread could compensate for the default pattern, but that is not the case. 


\section{7}

\section{Exploring the Enhancement Decision}

As previously mentioned, for a short period of time BNDES offered the borrower an option to take an additional leverage above the maximum participation, which we call "enhancement". This part of the loan above the maximum participation was fully funded at market prices, i.e., used Selic instead of TJLP as the base interest rate. The decision to enhance is an additional self selection mechanism that we can investigate for asymmetric information.

The enhancement option was available for several of BNDES credit lines ${ }^{1}$ from feb/2014 to dec/2016 and could be taken by borrowers freely if their intended credit line had that option. Between feb/2014 and dec/2015 it allowed for an enhancement in participation up to $90 \%$ and later this limit was reduced to $80 \%$.

First, Table (7.1) presents descriptive statistics of the subsample of loans contracted when the enhancement choice was offered.

${ }^{1}$ Mostly all lines whose maximum participation was bellow the limiting leverage established for the enhancement. 


\section{Table 7.1: Descriptive Statistics of the subsample of loans that could take the enhancement option}

Table reports descriptive statics from a subsample of BNDES indirect loans for investment of SMEs contracted when the enhancement option was offered by BNDES. Max Part is the maximum allowable leverage set by BNDES credit policy. Enhance Y.N. is a dummy indicating whether the borrower took (1) additional leverage funded in market cost or not (0). Grace stand for grace period. Amort stand for amortization period. Base Interest is the regular (in TJLP) BNDES loan interest rate. Enh Interest is the interest rate available for the enhancement loan (with market cost). I_Default is a dummy indicating whether the loan defaulted (1) or not (0). Perc_Pay is the fraction of the loan principal payments made up to the time when the sample was constructed (june/2019).

\begin{tabular}{lcccccc}
\hline \multicolumn{7}{c}{ Sample Size = 1,857 } \\
\hline Variables & Mean & St. Dev. & Min & Q1 & Q3 & Max \\
\hline Loan (R\$ 1K) & 440.72 & 851.86 & 7.99 & 122.10 & 332.53 & $14,578.17$ \\
Match Fund (R\$ 1K) & 14.68 & 244.46 & 1.99 & 41.67 & 109.07 & $7,149.84$ \\
Leverage \% & 74.12 & 12.39 & 17 & 70 & 80 & 90 \\
Max Part \% & 80.06 & 9.13 & 70 & 70 & 90 & 90 \\
Enhance Y.N. & $40.6 \%$ & 0.491 & - & - & - & - \\
Grace (months) & 4.53 & 3.94 & 0 & 3 & 6 & 24 \\
Amort (months) & 56.88 & 11.56 & 9 & 54 & 57 & 180 \\
Base Interest (\%/yr) & 10.10 & 2.35 & 6.50 & 9.00 & 9.50 & 22.79 \\
Enh Interest (\% /yr) & 19.28 & 1.88 & 9.73 & 17.96 & 20.45 & 25.77 \\
I_Default & $9.2 \%$ & 0.289 & - & - & - & - \\
Perc_Pay \% & 64.3 & 23.4 & 0.1 & 53.7 & 78.9 & 100 \\
\hline
\end{tabular}

It is worth noticing that there is a high incidence of borrowers who chose to enhance $(40.6 \%)$ when it was possible. On average the interest rate charged on the enhancement was 918 bps higher than the one in the regular participation constrained loan (a relevant 90\% higher rate). Default occurrences are, relatively, less frequent than in the full sample, and other loan characteristics are similar to the one in Table (3.2).

Borrowers in this subsample, made two decisions, first if they would take the maximum participation funded in TJLP, second, if they did chose the maximum participation whether they would take additional enhancement leverage at market cost. Each decision may be modelled as a Tobit (the first one with left censoring as before and the second one with a right zero bound censoring), and their residual can be constructed and included in the default regression exactly as before. That way we are able to evaluate separately the two credit demand decisions. Results are reported in Table (7.2). 
Table 7.2: Default regression with enhancement decision

Table reports Cox proportional hazards default regression estimates separating the leverage in a regular part funded in TJLP and an enhanced part funded in market cost. For each part of the leverage it is included a residual from the first stage demand estimate. Sample only contain loans contracted in the period when BNDES offered the enhancement option. Enhanced and Regular leverage are in percentage point. Small and Micro dummies for firm's size are reported with Medium size the reference category. Risk assessment dummies are reported with the best rating, AA-rating, as the reference category. Grace stands for the grace period in months. Amort stands for the amortization period in months. Total Investment is the project's total cost. All models have month and year fixed effects and each specification is presented with and without intermediary fixed effect.

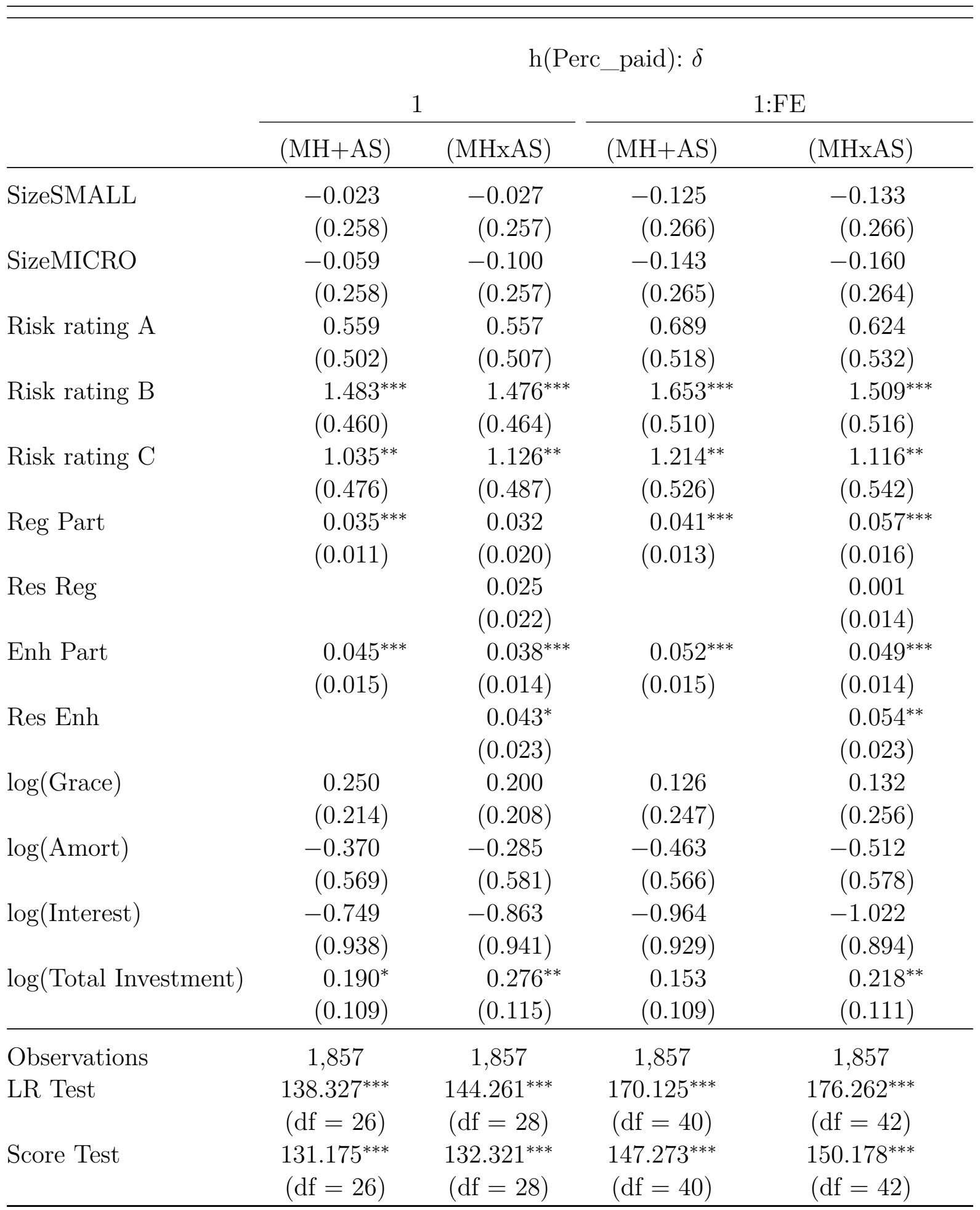

Notes: Values reported are the estimated coefficients with robust standard errors in parenthesis. Significance codes as follows: ${ }^{*} \mathrm{p}<0.1 ;{ }^{* *} \mathrm{p}<0.05 ;{ }^{* * *} \mathrm{p}<0.01$ 
Notice that the regular leverage has the same behaviour as the estimation with the whole sample in Table (5.3), i.e. a moral hazard effect (a 1\% increase in leverage leads to a $\left(e^{0.032}-1=\right) 325$ bps or $\left(e^{0.057}-1=\right) 586$ bps increase in the probability of default) that is partially offset by advantageous selection (decreasing the probability to default in $\left(e^{0.035-0.032}-1=\right) 30$ or 161 bps after a $1 \%$ increase in leverage due to unobservable reason).

However, the enhancement leverage decision contains a more relevant moral hazard effect (a $1 \%$ increase in leverage leads to a $\left(e^{0.038}-1=\right) 387$ or 502 bps increase in the probability of default) and also an adverse selection effect (increasing the probability to default in $\left(e^{0.052-0.049}-1=\right) 30$ or $70 \mathrm{bps}$ after a $1 \%$ increase in leverage due to unobservable reason).

This results can shed some light on the advantageous selection effect we found before. Since regular BNDES loans are funded below usual market costs, an increase in regular leverage (due to unobservable factors) may improve the project riskiness. When it comes to the decision of the enhancement leverage using a higher market-based cost, there is evidence of adverse selection, i.e., borrowers who opt to enhance the leverage on much higher rates are indeed (and unobservably to lenders) riskier than those who did not choose to take the enhancement.

Since the conditions of BNDES indirect loans are usually more favourable than market practices, a possible explanation for these results is that firms with better financial management consistently choose a higher regular leverage, and this better management also reduces default events later. On the other hand, taking the enhancement option and increasing the loan at much higher rates, is a decision that entails adverse selection and moral hazard, possibly associated with less diligent financial management. 


\section{8 \\ Conclusion}

As far as we know, this is the first study to directly investigate the presence of asymmetric information in Brazilian credit markets. This is also the first study on investment loans granted to SMEs in Brazil and it fits into the empirical literature on asymmetric information that is relatively scarce regarding credit to firms.

The key finding of moral hazard and advantageous selection is robust to different specifications albeit being potentially specific to the BNDES indirect loans context. When we explored the enhancement decision, the part of the leverage with interest rates similar to the ones practiced with free resources in the economy, we found evidence of adverse selection coupled with moral hazard.

The technique used in this study to separately identify moral hazard and adverse selection could be extended to the much larger sample of indirect loans by BNDES if we could access default data from these loans. Since our sample consist only of loans partially guaranteed by the FGI, any generalization of the analysis would require data on loans without FGI guarantees. BACEN-SCR is a potential source for this data, which would need to be matched one-by-one with the corresponding maximum participation defined by BNDES at the time the loan was granted.

Another way to extend the research is aggregating more data on the borrowers. It is reasonable to believe that intermediary banks have access to more information from the borrowers than it is informed to BNDES and some of these information could be obtained from other sources, including real outputs, from IBGE, and financial data, from BACEN or private data bureaus.

As discussed before, in this study we use the information set that the BNDES and the FGI have regarding BNDES indirect loans, so our diagnosis of asymmetric information is between these agents and the borrower. Hence, potential policies derived from our findings must be restricted to our setting.

The diagnosis of moral hazard could be used by FGI to charge higher prices on higher leveraged loans or by BNDES if it decides to bear some of the risk of a indirect loan. Also dynamic contracting schemes ${ }^{1}$ could be tested

\footnotetext{
${ }^{1}$ For example, for initial loans it is set a lower ceiling for leverage, if the borrower has no
} 
by BNDES and FGI to mitigate moral hazard in case it is (at least partially) behaviorally motivated.

The diagnosis of advantageous selection indicates that (ex-post) less riskier and observably identical borrowers demands more resources from BNDES which is undoubtedly desirable from a credit perspective, specially with public resources.

Lastly, there is the posing challenge (and a key objective of the FGI) of how to induce intermediary banks to lend to riskier (supposedly more credit constrained) borrowers while maintaining their incentives to operate with these indirect credit lines. Based on our findings, a segregate risk assessment could be explored to this end by separating the resources' allocation from the pricing of the loan in the following way: with independent (third-part) riskassessment of the loan pledge, BNDES and FGI could define, respectively, the leverage and the insurance coverage of the loan, using principles/rules that, for example, balances risk exposure and credit inclusion principles ${ }^{2}$. With all the characteristics of the loan defined but the interest rate, intermediary banks could price-compete for these loans ${ }^{3}$, assuring that the interest rate reflects the riskiness of the loan.

delinquency record in the initial loan, it could progressively apply for new loans with higher leverage limits.

${ }^{2}$ Possibly for borrowers with worse credit scores BNDES could assume part of the risk or FGI could provide a bigger coverage to induce intermediary banks to hire the loan.

${ }^{3}$ The "Canal MPME" from BNDES already operate as a central for loans pledges where intermediary banks could offer their credit solution. The proposition could easily derive from this platform by introducing a first stage of credit scoring and by changing the phase where banks compete to focus on the interest rate. 


\section{References}

[1] William Adams, Liran Einav, and Jonathan Levin. "Liquidity Constraints and Imperfect Information in Subprime Lending." In: American Economic Review 99.1 (2009), pp. 49-84.

[2] Sumit Agarwal, Souphala Chomsisengphet, and Chunlin Liu. "An empirical analysis of information asymmetry in home equity lending." In: Jornal of Financial Services Research 49 (2015). DOI: 10.1007/s10693-015-0216$z$.

[3] Sumit Agarwal, Souphala Chomsisengphet, and Chunlin Liu. "The Importance of Adverse Selection in the Credit Card Market: Evidence from Randomized Trials of Credit Card Solicitations." In: Journal of Money, Credit and Banking 42.4 (2010), pp. 743-754.

[4] George A. Akerlof. "The market for "lemons": Quality uncertainty and the market mechanism." In: Quarterly Journal of Economics 84.3 (1970), pp. 488-500.

[5] Leonardo Fernandes Alencar, Rodrigo Andrade, and Klenio Barbosa. "Bank Competition and the Limits of Creditor's Protection Reforms." In: 2017.

[6] Daniel Altman, David M. Cutler, and Richard J. Zeckhauser. "Adverse Selection and Adverse Retention." In: The American Economic Review 88.2 (1998), pp. 122-126.

[7] Antonio M. H. P. Ambrozio, Felipe L. de Souza, and André A. Faleiros João P. M. San'tAnna. "Credit scarcity in developing countries: An empirical investigation using Brazilian firm-level data." In: Economia 18.1 (2017), pp. 73-87.

[8] Juliano J. Assunção, Efraim Benmelech, and Fernando S.S. Silva. "Repossession and the Democratization of Credit." In: The Review of Financial Studies 27.9 (2014), pp. 2661-2689.

[9] Orazio Attanasio, P. Koujianou Goldberg, and Ekaterini Kyriazidou. "Credit Constraints in the Market for Consumer Durables: Evidence from Micro Data on Car Loans." In: International Economic Review 49.2 (2008), pp. 401-436. 
[10] Lawrance M. Ausubel. "Adverse Selection in the credit card market." In: http : // www . ausubel . com/ creditcard-papers/adverse. pdf (1999).

[11] Banco Central do Brasil BACEN. "Relatório de Economia Bancária." In: (2018).

[12] Klenio Barbosa, Bruno de Paula Rocha, and Fernando Salazar. "Assessing competition in the banking industry: A multi-product approach." In: Journal of Banking \& Finance 50 (2015), pp. 340-362.

[13] Thorsten Beck and Asli Demirguç-Kunt. "Small and medium-size enterprises: access to finance as a growth constraint." In: Journal of Banking \& Finance 30.11 (2006), pp. 2931-2943.

[14] Allen N. Berger, Marco A. Espinosa-Vega, et al. "Why do borrowers pledge collateral? New empirical evidence on the role of asymmetric information." In: Journal of Financial Intermediation 20 (2011), pp. 55-70.

[15] Allen N. Berger, W. Scott Frame, and Vasso lannidou. "Test of ex ante versus ex post theories of collateral using private and public information." In: Journal of Financial Economics 100 (2011), pp. 85-97.

[16] Helmut Bester. "The role of collateral in credit markets with imperfect information." In: European Economic Review 31 (1987), pp. 887-899.

[17] Eric W. Bond. "A direct test of the "lemons" model: the market for used pickup trucks." In: The American Economic Review 72.4 (1982), pp. 836840.

[18] James H. Cardon and Igal Hendel. "Asymmetric Information in Health Insurance: Evidence from the National Medical Expenditure Survey." In: The RAND Jornal of Economics 32.3 (2001), pp. 408-427.

[19] A. Chassagnon and P.A. Chippori. "Insurance under moral hazard and adverse selection: the case of pure competition." In: http : / / www . parisschoolofeconomics . com/ chassagnon-arnold/acpac95. pdf (1997).

[20] Pierre-Andre Chiappori, Franck Durand, and Pierre-Yves Geoffard. "Moral hazard and the demand for physician services: First lessons from a French natural experiment." In: European Economic Review 42 (1998), pp. 499511.

[21] Pierre-Andre Chiappori and Bernard Salanie. "Testing for asymmetric information in Insurance Markets." In: Jornal of Political Economy 108.1 (2000), pp. 56-78. 
[22] C. A. Coelho, J. M. P. de Mello, and L. Rezende. "Do public banks compete with private banks? Evidence from concentrated local markets in Brazil." In: Journal of Money, Credit, and Banking 45.8 (2013), pp. 1581-1615.

[23] Claudio R. De Lucinda and Rodrigo L. Vieira. "Interest rates and informational issues in the credit market: experimental evidence from Brazil." In: World Development 59 (2014), pp. 47-58.

[24] Will Dobbie and Paige M. Skiba. "Information Asymmetries in Consumer Credit Markets: Evidence from Payday Lending." In: American Economic Jounal: Applied Economics 5.4 (2013), pp. 256-282.

[25] Wendy Edelberg. "Testing for adverse selection and moral hazard in consumer loan market." In: FEDS Working Paper No. 2004-09 (2004).

[26] Liran Einav, Amy Finkelstein, and Mark R. Cullen. "Estimating welfare in insurance markets using variation in prices." In: The Quarterly Journal of Economics 125.3 (2010), pp. 877-921.

[27] Liran Einav, Mark Jenkins, and Jonathan Levin. "Contract Pricing in Consumer Credit Markets." In: Econometrica 80.4 (2012), pp. 1387-1432.

[28] Daniela A. Fontes. "Three essays using home and kitchen appliances sales data." In: http: //www2. dbd. puc-rio. br/pergamum/biblioteca/ php $/$ mostrateses . php? open=18arqtese $=0721279_{\text {_ }} 2012_{\text {_ }}$ Indice. html (2012).

[29] David Genesove. "Adverse selection in the wholesale used car market." In: Journal of Political Economy 101.4 (1993), pp. 644-665.

[30] Xavier Giné, Jessica Goldberg, and Dean Yand. "Credit market consequences of improved personal identification: field experiment evidence from Malawi." In: American Economic Review 102.6 (2012), pp. 2923-2954.

[31] John S. Gonas, Michael J. Highfield, and Donald J. Mullineaux. "When Are Commercial Loans Secured?" In: Financial Review 39.1 (2004), pp. 79-99.

[32] Christopher Hansman. "Asymmetric Information and the Link Between Leverage and Mortgage Default." In: 2017.

[33] Andrew Hertzberg, Andres Liberman, and Daniel Paravisini. "Screening on Loan Terms: Evidence from Maturity Choice in Consumer Credit." In: The Review of Financial Studies 31.9 (2018), pp. 3532-3567.

[34] Dwight. M. Jaffe and Franco Modigliani. "A Theory and Test of Credit Rationing." In: The American Review 59.5 (1969), pp. 850-872. 
[35] Dwight. M. Jaffe and Thomas Russel. "Imperfect Information, Uncertainty and Credit Rationing." In: The Quarterly Jounal of Economics 90.4 (1976), pp. 651-666.

[36] Gustavo Joaquim and Bernardus Van Doornik. "Market Power in Financial Intermediation: Evidence and Theory." In: Working paper unpublished (2018).

[37] Dean Karlan and Jonathan Zinman. "Observing unobservables: identifying information asymmetries with a consumer credit field experiment." In: Econoometrica 77.6 (2009), pp. 1993-2008.

[38] Luciano Q. Lanz, João V. Perufo, and Fernando A. O. Mantese. "Fundo Garantidor para microcrédito: proposta de um modelo." In: Temas de Administração Pública 9.2 (2014).

[39] Luiz A. Lucente. "Relationshhip banking: does it lowers information asymmetry or increase lender monopoly power?" In: http://hdl. handle. net/10438/11527 (2014).

[40] Gabriela Pásztorová. "Does Loan Maturity Matter in Risk-based Pricing? Evidence from Consumer Loan Data." In: ATINER'S Conference Paper Series, No: ECO2013-0794 (2013).

[41] Jacopo Ponticelli and Leonardo S. Alencar. "Court Enforcement, Bank Loans, and Firm Investment: Evidence From a Bankruptcy Reform in Brazil." In: The Quarterly Journal of Economics 131.3 (2016), pp. 1365-1413.

[42] Robert Puelz and Arthur Snow. "Evidence on adverse selection: equilibrium signalling and cross-subsidizarion in the insurance market." In: Jornal of Political Economy 102.2 (1994), pp. 236-257.

[43] Michael Rothschild and Joseph Stiglitz. "Equilibrium in competitive insurance markets: an essay on the economics of imperfect information." In: Quarterly Journal of Economics 90.4 (1976), pp. 629-649.

[44] Luiz C. F. Sacramento Junior. "More Than Words: Broader information sharing and access to the formal credit market." In: $h t t p: / / h d l$. handle. net/10438/18293 (2017).

[45] Serviço Brasileiro de Apoio às Micro e Pequenas Empresas SEBRAE. "Relatorio Especial - O financiamento das MPME no Brasil." In: (2017).

[46] Joseph E. Stiglitz and Andrew Weiss. "Credit Rationing in Markets with Imperfect Information." In: The American Economic Review 71.3 (1981), pp. 393-410. 
[47] Otto Toivanen and Robert Cressy. "Is there adverse selection in the credit market?" In: Venture Capital: An International Journal of Entrepreneurial Finance 3.3 (2001), pp. 215-238.

[48] Kenneth Train. Discrete Choice models with simulation. Cambridge University Press, 2003.

[49] Hirofumi Uchida, lichiro Uesugi, and Hiromichi Iwaki. "Adverse Selection versus Moral Hazard in Financial Contracting: Tests taking advantage of the introduction of non-collateralized loans." In: HIT-REFINED Working Paper Series No. 83 (2018).

[50] Adam G. Walke, Thomas M. Jr Fullerton, and Robert J. Jr. Tokle. "Riskbased loan pricing consequences for credit unions." In: Journal of Empirical Finance (2018). DOI: doi.org/10.1016/j.jempfin.2018.02.006.

[51] James Wang. "Decomposing moral hazard in lending: evidence from China." In: Phd dissertation Ch2 - http: // hdl. handle. net/2027. 42/111510 (2005).

[52] Felipe Zambaldi et al. "Credit granting to small firms: A Brazilian case." In: Journal of Business Research 64 (2011), pp. 309-315. 


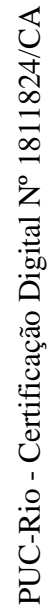




\section{9}

\section{Appendix}

\section{Table A.1: Non-censored credit demand}

Table reports non-censored regression estimates of Equation (4-1). Leverage in percentage point is the dependent variable. Small and Micro dummies for firm's size are reported with Medium size the reference category. Risk assessment dummies are reported with the best rating, AA-rating, as the reference category. Grace stands for the grace period in months. Amort stands for the amortization period in months. Enhance Y.N. is a dummy variable taking the value of 1 if the borrower opted to take a leverage beyond the maximum participation funded at market cost and 0 otherwise. Total Investment is the project's total cost. Scale is the standard deviation of Tobit idiosyncratic error. Specification (2) differs from specification (1) by the inclusion of Brazilian base interest rate, the Selic. All models have month and year fixed effects and each specification is presented with and without intermediary fixed effects.

\begin{tabular}{|c|c|c|c|c|}
\hline & \multicolumn{4}{|c|}{ Leverage } \\
\hline & $(1)$ & $(1: \mathrm{FE})$ & $(2)$ & $(2: \mathrm{FE})$ \\
\hline (Constant) & $\begin{array}{l}33.578^{* * *} \\
(1.695)\end{array}$ & $\begin{array}{l}23.579^{* * *} \\
(6.236)\end{array}$ & $\begin{array}{l}24.494^{* * *} \\
(3.068)\end{array}$ & $\begin{array}{l}14.517^{* *} \\
(6.723)\end{array}$ \\
\hline SizeSMALL & $\begin{array}{l}-1.710^{* * *} \\
(0.381)\end{array}$ & $\begin{array}{l}-1.551^{* * *} \\
(0.374)\end{array}$ & $\begin{array}{l}-1.728^{* * *} \\
(0.380)\end{array}$ & $\begin{array}{l}-1.580^{* * *} \\
(0.374)\end{array}$ \\
\hline SizeMICRO & $\begin{array}{c}-8.233^{* * *} \\
(0.327)\end{array}$ & $\begin{array}{l}-5.918^{* * *} \\
(0.360)\end{array}$ & $\begin{array}{l}-8.267^{* * *} \\
(0.327)\end{array}$ & $\begin{array}{c}-5.974^{* * *} \\
(0.360)\end{array}$ \\
\hline Risk rating $\mathrm{A}$ & $\begin{array}{l}-3.411^{* * *} \\
(0.249)\end{array}$ & $\begin{array}{c}0.488 \\
(0.330)\end{array}$ & $\begin{array}{l}-3.383^{* * *} \\
(0.249)\end{array}$ & $\begin{array}{c}0.507 \\
(0.330)\end{array}$ \\
\hline Risk rating $B$ & $\begin{array}{l}-1.829^{* * *} \\
(0.234)\end{array}$ & $\begin{array}{l}1.850^{* * *} \\
(0.308)\end{array}$ & $\begin{array}{l}-1.782^{* * *} \\
(0.234)\end{array}$ & $\begin{array}{l}1.888^{* * *} \\
(0.308)\end{array}$ \\
\hline Risk rating $\mathrm{C}$ & $\begin{array}{l}-1.028^{* * *} \\
(0.282)\end{array}$ & $\begin{array}{l}2.247^{* * *} \\
(0.358)\end{array}$ & $\begin{array}{l}-0.972^{* * *} \\
(0.283)\end{array}$ & $\begin{array}{l}2.291^{* * *} \\
(0.358)\end{array}$ \\
\hline $\log ($ Grace $)$ & $\begin{array}{l}0.395^{* *} \\
(0.173)\end{array}$ & $\begin{array}{c}-0.156 \\
(0.213)\end{array}$ & $\begin{array}{l}0.348^{* *} \\
(0.173)\end{array}$ & $\begin{array}{c}-0.204 \\
(0.213)\end{array}$ \\
\hline $\log$ (Amort) & $\begin{array}{l}16.798^{* * *} \\
(0.346)\end{array}$ & $\begin{array}{l}15.450^{* * *} \\
(0.444)\end{array}$ & $\begin{array}{l}16.851^{* * *} \\
(0.346)\end{array}$ & $\begin{array}{l}15.462^{* * *} \\
(0.444)\end{array}$ \\
\hline $\log ($ Interest $)$ & $\begin{array}{l}-3.101^{* * *} \\
(0.362)\end{array}$ & $\begin{array}{l}-2.524^{* * *} \\
(0.355)\end{array}$ & $\begin{array}{l}-4.115^{* * *} \\
(0.461)\end{array}$ & $\begin{array}{c}-3.539^{* * *} \\
(0.453)\end{array}$ \\
\hline $\log ($ Selic $)$ & & & $\begin{array}{l}4.406^{* * *} \\
(1.240)\end{array}$ & $\begin{array}{l}4.380^{* * *} \\
(1.218)\end{array}$ \\
\hline Enhance.Y.N. & $\begin{array}{l}17.162^{* * *} \\
(0.517)\end{array}$ & $\begin{array}{l}17.777^{* * *} \\
(0.518)\end{array}$ & $\begin{array}{l}17.291^{* * *} \\
(0.518)\end{array}$ & $\begin{array}{l}17.885^{* * *} \\
(0.519)\end{array}$ \\
\hline $\log ($ Total Investment) & $\begin{array}{c}-1.230^{* * *} \\
(0.101) \\
\end{array}$ & $\begin{array}{c}-1.264^{* * *} \\
(0.099) \\
\end{array}$ & $\begin{array}{c}-1.235^{* * *} \\
(0.101) \\
\end{array}$ & $\begin{array}{c}-1.270^{* * *} \\
(0.099) \\
\end{array}$ \\
\hline Time FE & $Y$ & $Y$ & $Y$ & $Y$ \\
\hline Intermediary FE & $N$ & $Y$ & $N$ & $Y$ \\
\hline F Statistic & $\begin{array}{c}275.474^{* * *} \\
(\mathrm{df}=30 ; 15196)\end{array}$ & $\begin{array}{c}201.672^{* * *} \\
(\mathrm{df}=48 ; 15178)\end{array}$ & $\begin{array}{c}267.199^{* * *} \\
(\mathrm{df}=31 ; 15195)\end{array}$ & $\begin{array}{c}197.976^{* * *} \\
(\mathrm{df}=49 ; 15177)\end{array}$ \\
\hline
\end{tabular}

Notes:Robust standard errors in parenthesis. Significance codes as follows: ${ }^{*} \mathrm{p}<0.1$; ${ }^{* *} \mathrm{p}<0.05 ;{ }^{* * *} \mathrm{p}<0.01$ 